April 2019. Forthcoming in Poetics.

\title{
HOW CLASS IDENTITIES SHAPE HIGHBROW CONSUMPTION: A CROSS-NATIONAL ANALYSIS OF 30 EUROPEAN COUNTRIES AND REGIONS*
}

\author{
Aaron Reeves ${ }^{\dagger}$
}

April 10, 2019

\begin{abstract}
:
Highbrow culture may not always be central to cultural capital and, in such circumstances, the distinctiveness of middle-class consumption of highbrow culture may diminish, becoming more similar to working-class consumption. Using data from 30 European countries, I explore this issue through examining three questions: 1) is class identity associated with highbrow consumption; 2) does this association vary across countries; and 3) is the relationship between class identity and highbrow consumption altered when the majority of people in a given society identify as either 'working-class' or 'middle-class'? After accounting for other socio-demographic controls, people who identify as middle-class are more active highbrow consumers than those who identify as working class. Yet, the distinctiveness of middle-class consumption of highbrow culture varies across countries and is negatively correlated with how many people identify as working-class in a society. As more people identify as working-class (rejecting middle-class identities) highbrow culture less clearly distinguishes middle-class and working-class identifiers. In the absence of any class-structured divisions in highbrow culture, whether and how cultural practices function as a form of cultural capital is likely quite different, reinforcing the claim that the centrality of highbrow culture to cultural capital varies geographically.
\end{abstract}

\section{INTRODUCTION}

Highbrow culture is often assumed to be a central component of cultural capital because the practices which are regarded as highbrow (activities such as opera, ballet or visiting galleries) have long been 'the most general form of prestigious culture' in most Western societies (DiMaggio and Mukhtar 2004) and because these practices are commonly associated with "higher

\footnotetext{
*Replication materials are available here: https://github.com/asreeves/class-identities-culture

${ }^{\dagger}$ University of Oxford, aaron.reeves@spi .ox . ac . uk
} 
moral and aesthetic values' (Lizardo 2006a: 782). There is, however, no a priori reason why traditional or highbrow culture should function in this way. To be sure, a vast number of studies have documented a distinctive pattern of highbrow consumption among those occupying privileged social positions, such as the highly educated (Bennett et al. 2009), and this distinctiveness is then often used as evidence to argue that these activities constitute cultural capital. Others have questioned whether highbrow culture, always and everywhere, helps people secure social advantages associated with cultural capital, such as access to elite networks (Edelmann and Vaisey 2014) or even higher earnings (Reeves and Vries 2018). Documenting where highbrow culture becomes cultural capital has proven challenging; but what seems clear is that whether and how it functions as a form of distinction will be quite different when highbrow culture is not also a 'class structured opposition', that is, when both the middle- and working-classes are equally engaged in highbrow culture. While it might be too strong to argue that 'the exclusive respect traditionally accorded to "highbrow" cultural pursuits has largely dissolved' (Lareau and Weininger 2003), there is evidence from some European countries that the role highbrow culture plays in marking class distinctions is not entirely straightforward (Prieur and Savage 2013). This is not a European phenomenon only, with some in the U.S. also arguing 'the position of the high culture arts' as a form of cultural capital 'is declining' (DiMaggio and Mukhtar 2004). The degree to which we see 'class structured oppositions' in highbrow culture may in fact vary substantially between contexts.

One limitation of the argument that highbrow culture does not always play an important role in marking class distinctions is that much of the research elucidating the ambiguous connection between highbrow culture and class distinctions, e.g., debates about 'emerging cultural capital', relies on data from only one or two countries (Jarness and Friedman 2017; Lamont 1992; Prieur, Rosenlund, and Skjott-Larsen 2008), making it difficult to draw strong conclusions about relative differences in highbrow cultural consumption between classes in distinct settings. It is unlikely that merely narratively synthesising unrelated studies from disparate countries will produce generaliseable conclusions. This is especially challenging if, as is often the case, each study deploys quite different data collection procedures. In fact, those crossnational studies that do rely on comparable data collection processes point in a different direction. In 'very different country contexts with varying cultural policies and economic conditions', the affluent, the highly educated, and the high status are all more likely to be highbrow cultural consumers (Falk and Katz-Gerro 2016), suggesting the claim that highbrow culture does not mark class distinctions may be over-stating the case.

Another challenge to the view that highbrow cultural consumption is not always central to cultural capital is that a clear account of the basis on which 'class structured oppositions' in highbrow consumption may differ across countries remains elusive. It is commonly argued that whether a specific cultural practice constitutes cultural capital is shaped by the 'field' in which it is embedded (Krause 2018) and the institutions which classify and legitimate different art forms (DiMaggio 1987); and yet whether such variation between contexts is random or systematic is largely unknown. In other words, if the difference in highbrow consumption between social groups is smaller in Finland than in Germany, for example, is this due to some historical accident or is this difference rooted in underlying social processes that are observable across many countries? This continues to be one of the 'questions that have not yet been 
answered' in comparative work on cultural consumption (Katz-Gerro 2011). But this question is more than just a gap in our knowledge; it has 'tremendous implications' for how we understand cultural stratification and its connection with the shape and structure of inequality across countries and over time (Katz-Gerro 2011).

This paper moves these debates forward by developing one of the crucial but underexplored insights that have emerged from some of those case studies which have illuminated how highbrow consumption varies across countries. Beyond merely revealing cross-national differences, these case studies have repeatedly stressed the importance of class identities - not just occupation or education - to understanding patterns of highbrow consumption throughout Europe (Pape, Rossel, and Solga 2012; Reeves, Gilbert, and Holman 2015). The centrality of class identities to some domains of social life has declined (e.g., politics) (Evans and Tilley 2012), but I argue class identities have simultaneously become more central to issues of cultural consumption and cultural capital (Devine and Savage 2005). This is because: (i) such identities represent symbolic communities that often share similar lifestyles, values, and dispositions; (ii) such identities involve 'position taking', a way of locating oneself within the social space; and (iii) such identities are 'relational', that is how someone describes their class identity is influenced by how others around them describing their class identities too (Flemmen, Jarness, and Rosenlund 2017; Martin and Merriman 2015).

This paper, then, explores how class identities are correlated with highbrow consumption within and between countries using a cross-nationally comparable data set covering $30 \mathrm{Eu}-$ ropean countries and regions. I ask three main questions: is class identity associated with highbrow consumption; does this association vary across countries; and is the relationship between class identity and highbrow consumption altered when the majority of people in a given society identify as either 'working-class' or 'middle-class'?

Taken together, the results indicate that, after accounting for other measures of social stratification, people who identify as middle-class consume more highbrow culture than those who identify as working class. There is, however, considerable variation in this relationship between countries. Highbrow consumption is a 'class structured opposition', but this is strongest in countries where the majority of people also identify as middle-class. By contrast, in countries where the proportion of people who identify as working class is greater, the distinctiveness of highbrow consumption among people who identify as middle-class diminishes, becoming more similar to those who identify as working-class. In these countries, highbrow consumption seems to play a less important role in marking class distinctions (DiMaggio and Mukhtar 2004), suggesting that cultural capital is enacted through other class structured oppositions.

\section{CLASS IDENTIFICATION AND HIGHBROW CULTURE}

Class identification reflects how people think about their social position (Bottero 2004), it is one of the ways people articulate 'what is salient about their lives' (Wright 1997: 497). When people describe themselves as middle- or working-class they are 'taking a position' with respect to the social hierarchy in their society and they are simultaneously declaring their membership 
in particular symbolic communities (Flemmen et al. 2017; Lamont and Molnar 2002). While income, education, and status will have some bearing on whether people identify with particular symbolic communities (Hout 2008; Sosnaud, Brady, and Frenk 2013), these identities will also be concerned with the symbolic value of specific class labels (such as 'middle class').

The force and coherence of class identities has diminished in some areas of social life, such as politics (Evans and Tilley 2012), but they remain, I argue, intimately tied to cultural consumption. Being middle-class, for example, involves not simply an occupational position but evokes a series of tastes and practices commonly ascribed to those groups (Lamont 1992). Vignette studies are able to gesture toward social class identities through describing what people wear, where they eat, and what television shows they watch (Pape et al. 2012; Reeves et al. 2015). These studies work because class identities entail cultural identities too. ${ }^{1}$

Highbrow cultural forms have historically been intimately connected to the formation of middleclass identities in many contexts, giving them broad currency across Western societies (DiMaggio and Mukhtar 2004). These activities were central to the cultivation of a particular way of being in the world (Bourdieu 1984) and so the arts, and the high arts in particular, were imbued with the capacity to inculcate a set of more refined moral and aesthetic sensibilities (Lizardo 2006a). High culture - practices such as reading and going to libraries, visiting galleries or museums, attending the opera or the ballet, visiting stately homes or other historic sites - is prestigious, of course, because it has been legitimatized by the state and institutions of higher learning (Larsen 2016). This legitimation has occurred through both public investment (e.g., financing artistic practices) and through the creation of a cultural canon (which marked out those art forms worthy of serious attention) (Levine 1988; Upchurch 2004).

Given this longstanding symbolic congruence between class labels and cultural practice (DiMaggio 1987), we might expect that - irrespective of occupation, age, sex, and education - people who self-identify as 'middle-class' might be more likely to be highbrow consumers than those who identify as 'working-class'. This is because there is no set of sufficient conditions for becoming middle-class, rather there is only a nebulous collection of values, practices, and symbols. People may identify as middle-class on the basis of their highbrow consumption without necessarily possessing some of the other symbols of middle-class identities, such as a professional occupation (Skeggs 2004). In fact, adopting the cultural tastes of the middle-classes is far easier and cheaper than changing careers. Conversely, it is also possible for people in professional jobs with university degrees and high salaries to identify as working-class, especially claiming a middle-class identity is undesirable.

\section{HIGHBROW CONSUMPTION AND THE CLASS IDENTITIES OF OTHERS}

When someone claims a middle-class identity they are not only locating themselves with respect to others who are 'middle-class', but they are also taking a position in relation to those who identify as 'working-class' (Lizardo and Skiles 2016b; Savage, Silva, and Warde 2010).

\footnotetext{
${ }^{1}$ There will also be important differences between how people who identify as working-class represent the perceived attitudes and behaviour of other members of the in-group versus how a member of the out-group (e.g., people who identify as middle-class) will represent the perceived attitudes and behaviour of the working-classes.
} 
Class identities, then, are a 'relational' form of 'position taking' and so, I argue, differences across countries in the proportion of people who identify as 'middle-class' may reflect the country-specific symbolic values attached to those class positions. Europeans are often averse to describing themselves as middle class, sometime because this is seen as symbolically placing oneself above another (Savage et al. 2010) or because it conflicts with egalitarian norms (van Eijk 2013; Ljunggren 2017). ${ }^{2}$

This is not just hypothetical. Describing oneself as working-class varies dramatically across European countries (Evans and Mills 1999). Sweden and Luxembourg are among the lowest ( $20 \%$ identify as working-class) while Spain and Portugal are among the highest (with more than $60 \%$ identifying as working-class). More people identify as working-class in poorer countries, of course, but even among the richer countries the differences are quite pronounced. Only 24\% of people in Denmark identify as working-class while almost $37 \%$ identify as workingclass in Finland. Similarly, only 19\% of people in The Netherlands identify as working-class while almost $50 \%$ of people in Great Britain describe themselves in the same way. ${ }^{3}$ Importantly, this is not simply driven by differences in access to education or the occupational structure within societies. There is still marked variation in whether people identify as 'middle-class' within relatively privileged social positions in every European country, such as those employed in professional occupations. In the Netherlands, $95 \%$ of professionals describe themselves as middle-class while only 70\% of professionals in Great Britain describe themselves in the same way. ${ }^{4}$ If, as argued above, people who identify as 'middle-class' consume more highbrow culture then we might expect countries with fewer 'middle-class' people to be, on average, less avid consumers of highbrow culture.

Variation in how people identify with specific class positions raises another question: does the relationship between middle-class identities and highbrow consumption depend on how many people within a society identify as 'middle-class'? In other words, is the relationship between highbrow culture and middle-class identities different within the Netherlands (where only 19\% of the population describe themselves as 'working-class') and Great Britain (where nearly 50\% of the population describe themselves as 'working-class')?

Recent work in this area suggests an intriguing hypothesis: the widespread adoption of working-

\footnotetext{
${ }^{2}$ One of the striking features of much class analysis during the latter half of the twentieth century was the declining importance of class identities during a period of rising economic and class inequality (Skeggs 2004). Respondents to survey questions asking them to describe their class position increasingly observed people disidentifying from - that is, refusing to accept the labels of - middle- and working-class identities. When we look at patterns of class dis-identification across Europe we see a slightly different pattern. On average, only around $4 \%$ of people in the surveyed European countries do not provide an answer to this question. In short, class identification still plays an important role in European societies.

${ }^{3}$ Of course, this could be simply due to the terms used in this particular question. However, a similar measure from the same survey asked "Could you please tell me where you would place yourself on the following scale?" (Where ' 1 ' = "the lowest level in society" and '10' = "the highest level in society"). Even on this measure, the gaps are surprisingly large. Only $8 \%$ of the Dutch place themselves in the lower categories (1-4) while over $16 \%$ of the British place themselves in the same category.

${ }^{4}$ In Great Britain, for example, $75 \%$ of people with 11 years or more of education identify as 'middle-class' while in the Netherlands $89 \%$ of people with the same level of education identify as 'middle-class'.
} 
class identities within a society may alter how people who identify as 'middle-class' consume highbrow culture. As noted above, Europeans often resist identifying with advantaged social positions in part because they fear the charge of snobbery, a pattern observed in Sweden (Karlsson 2005, 2017), the Netherlands (van Eijk 2013), Denmark (Harrits and Pedersen 2018), Norway (Ljunggren 2017), and the UK (Savage, Bagnall, and Longhurst 2001; Savage et al. 2010). This ambivalent connection with privileged social positions may also influence whether and how people consume highbrow culture. In an experimental vignette study, Reeves et al. (2015) find people are much less likely to express positive preferences for highbrow music once they have been randomly assigned to read a vignette describing a 'working-class' person who they believe would 'dislike' highbrow culture. By contrast, participants who were randomly assigned to read a 'middle-class' vignette were just as likely to express positive preferences toward highbrow music as those who did not read any vignette. Approaching this question from a different direction - but with results that are largely consistent with this earlier work - another experimental study finds that preferences for some lowbrow culture is higher when high-status individuals feel insecure about their high-status position (Hahl, Zuckerman, and Kim 2017).

Translating these findings to Europe more broadly, we might expect high-status Europeans to express lower levels of highbrow consumption because they may fear presenting themselves as being above another, that is, they feel somewhat insecure' about their high-status positions. This type of behaviour is quite well documented in Norway, for example, where elites cultivate an image of 'conspicuous modesty' (Daloz 2007) by avoiding discussion education and titles (Skarpenes and Sakslind 2010) and by downplaying social hierarchies in cross-class encounters (Gullestad 1985); but similar processes are also seen in Finland (Jarness and Flemmen 2019; Kantola and Kuusela 2018). This type of insecurity or uncertainty may be more prevalent in a society where a larger proportion of people identify as 'working-class', and who also potentially look down on 'highbrow' culture. Building on these studies, I argue that people who identify as middle class will consume less highbrow culture in countries where more people identify as 'working-class'. More precisely, the degree to which highbrow culture is a 'class structured opposition' will be reduced in countries where the majority of people identify as working-class.

\section{DATA AND METHOD}

To explore these questions, I use data from the nationally representative Eurobarometer 79.2 conducted between April and May 2013 (European Commission 2013), which included a special module on highbrow consumption related to music, television, and the arts. The Eurobarometer is designed to regularly monitor the social and political attitudes of the EU and other European countries (30 countries or regions). The full sample is based on face-to-face interviews with 27,563 people. All of these individuals are included in our main analyses, except for those who reported being in full-time education past the age of $30(n=590)$. After removing individuals who were missing on some of the covariates $(n=486)$, I have a final sample of 26,480. As a sensitivity check, I test whether the findings are consistent if I remove from the analysis those who are still in full time education or those who are under the age of 25 and over the age of 75 (Hek and Kraaykamp 2013). 
The main dependent variable is derived from the Eurobarometer's cultural practice index (Hek and Kraaykamp 2013). I am primarily interested in highbrow practices, that is, 'prestigious' activities which are commonly associated with 'higher moral and aesthetic values' (Lizardo 2006a: 782; DiMaggio and Mukhtar 2004). Not all of the activities included in the Eurobarometer's original list neatly fit within this definition (Lagaert and Roose 2018). For example, going to a concert or to the cinema is not necessarily associated with 'higher moral and aesthetic values', even though there are forms of both concert-going and visiting the cinema that are linked with these 'higher' aesthetic sensibilities. I have amended the original index to include only those practices most closely associated with highbrow consumption, specifically those questions asking people whether they have, in the last 12 months: 1) watched or listened to a cultural programme on TV or on the radio, 2) read a book, 3) visited a historical monument, 4) visited a museum or gallery, 5) visited a public library, 6) been to the theatre, 7) seen a ballet, a dance performance or an opera. Respondents were then given scores depending on how many times in the last 12 months they had participated in each of these activities $(0=$ never, $1=1-2$ times, $2=3-5$ times, 3 = more than 5 times). Following the standard measure from the Eurobarometer, these scores were added together to create a cumulative index of cultural practice, where people who scored 14 to 21 were labelled 'Very high', scores of 11 to 13 were 'High', scores of 5 to 10 were 'Medium', and scores of 0 to 4 were labelled 'Low'. As a sensitivity test, I also re-estimate the models with the original scale (0-21).

The key predictor of interest is "Do you see yourself and your household belonging to the working class of society, the middle class of society, the upper class of society, or other?" I recode this variable into a three-category variable: $1=$ working class, $2=$ middle- or upper-class, and 3 = 'other', 'don't know' or 'refuse' to provide an answer. Upper- and middle-class responses have been combined because, on average, only 23 people in each region described themselves as upper-class. This measure is especially useful because the Eurobarometer does very little 'arm-twisting' to elicit responses to these variables and so, because this is the only question related to subjective class position, it is unlikely respondents are providing 'nonattitudes' as a way of satisficing. Respondents could have just as easily answered 'Don't know' to this question and the interviewer would have moved on. Around $4 \%$ of the whole sample choose to provide an ambiguous answer, suggesting Europeans are familiar with this conception of class and know how to locate themselves in their national social hierarchy. ${ }^{5}$

The subjective nature of this measure may, at first glance, seem a weakness of this particular question; but it is also what makes it especially interesting. Respondents who describe themselves as middle-class have no fixed reference group regarding what counts as middle class. They must solely rely on heuristics and stereotypes of the middle class within their own country, and then use these to position themselves with respect to this imagined, national social

\footnotetext{
${ }^{5}$ To ensure these data are a good representation of subjective social class in these countries, I compare the data collected on this measure of subjective social class from the 2013 Eurobarometer to the data on the same question collected on the 2014 European Election study. The correlation between the proportion of people identifying as middle- or upper-class in each country across both surveys is 0.93 . Plus, the average level of non-response across the same set of countries in the 2014 European Election Study is 4.34\%, while $4.29 \%$ provided a non-response to this question in the Eurobarometer. These data from the European Election Study reinforce the accuracy of the data on subjective social class collected in the Eurobarometer.
} 
hierarchy. Of course, people will be reflexive about responding to such questions - considering how their answer might be perceived - but this is what makes this question a useful measure of respondent's views of their national social hierarchies and their position within them; people are very much aware that they are performing class positions through how they respond (Skeggs 2004). It is precisely this performative and reflexive dimension of subjective class positions that I want to analyse in this study. ${ }^{6}$

To measure how widespread working-class identities are in the population, I calculate the proportion of the population in each country that describe themselves as working-class. ${ }^{7}$ This population level measure of class identities, captures how people in a society see social hierarchies. Describing yourself as working-class in a society where approximately $50 \%$ of people make the same claim (e.g., Great Britain) means something quite different than it does in society where less than $20 \%$ of people describe themselves as working-class (e.g., The Netherlands). Of course, this does not mean that cross-national variation in how people respond to these questions make answers in one country completely incommensurable with answers in another country; all European countries appear to possess a sense that 'middle class' signifies professional and managerial occupations or social groups with more education and/or status (see Web Appendix 1 for a linear multilevel regression model exploring these associations). ${ }^{8}$ What, then, does variation in the proportion of people describing themselves as working-class mean? I argue that it captures something about the social significance of the 'middle class' label; that is, when people systematically reject the middle-class label they are rejecting a specific but symbolic feature of what it means to be 'middle class' in a particular society. By including a measure of the aggregate level of working-class identification in the model, I am hypothesising that how societies view social hierarchies shape patterns of highbrow culture and that it influences the relationship between class identities and highbrow culture.

Individual-level controls include age, age-squared, gender, the number of years of education, marital status, and type of community $(0=$ rural, $1=$ small- or medium-sized town, $2=$ city) (see Web Appendix 2 for descriptive statistics for these measures). Economic conditions at the individual and at the national level may shape how people respond to such a question and so

\footnotetext{
${ }^{6}$ As a sensitivity test, I examine whether the results are consistent if an alternative measure of social position is used, namely, "Could you please tell me where you would place yourself on the following scale?" (Where '1' = "the lowest level in society" and '10' = "the highest level in society"). This has been recoded so that people who score 1-6 are distinguished from those who score 7-10. Across the whole sample, approximately $52 \%$ of people describe themselves as middle-class while approximately $23 \%$ of people describe themselves as in a 'high level' in society.

${ }^{7}$ As the proportion of people who describe themselves as working-class increases the proportion of people who describe themselves as middle-class declines. It is not quite a zero-sum game - because of the 'other' category - but it is close. The correlation between these two variables is -0.98 .

${ }^{8}$ The within-country standardized regression coefficients (adjusted for age and sex) between subjective class identity and subjective social status were all positive, ranging between 0.212-0.494. Similarly, the standardized regression coefficients (adjusted for age and sex) between subjective class identity and years of education were all positive, ranging between $0.113-0.332$ with Malta being the only exception with a coefficient of almost zero (0.007). Finally, the standardized regression coefficients (adjusted for age and sex) between subjective class identity and professional and managerial occupations were all positive, ranging between 0.104-0.429. Taken together, this suggests that, in every country, the people who identify as middle class are, on average, educated professionals who earn high wages.
} 
I include a measure of labour market status in the regression model (which are a series of binary indicators measuring whether people are working in Professional and Managerial, Lower Professional, Routine non-manual, or Manual occupations, are self-employed, or whether they are retired, a student, a homemaker, or unemployed). Age may capture both true age-effects or cohort-effects in class identification and cultural practice (Reeves 2016). Gender influences patterns of cultural practice but is also associated with class identification (Lizardo 2006b); women are more likely to describe themselves as middle-class compared to working-class in these data. Education is a measure of social position, is highly correlated with occupation in most societies, and is one of the strongest predictors of cultural practice in almost every country for which data is available (Chan 2013). In this dataset, education is only measured as the number of years in full-time education and, while less than ideal in some settings (Schneider 2010), is a standard measure of educational attainment across countries which also captures an important dimension of social prestige within a specific country (Breen and Jonsson 2005). Middle class identities may be more common among married people but being married also affects cultural practice, for example, single people tend to be the most culturally active (KatzGerro and Sullivan 2010). Cultural practices of the kind measured in this survey will often be practised in towns and cities and so will be less accessible (and more costly to attend) for people in rural communities (Katz-Gerro 2002). In addition, the middle-class are also more common in suburban areas than in rural villages, although the relationship is certainly not deterministic, suggesting the middle-classes will have easier access to these activities.

In a series of additional analyses, I also explore whether the coefficients of interest are altered by other country-level predictors, including: the occupational structure of the country (i.e., the proportion of the employed population in service occupations); the wealth of the country (Gross National Income); the rate of social mobility (the percentage of people in a country who attained a higher final educational level than their father and/or mother) (Hek and Kraaykamp 2013); the level of government spending per capita on funding the cultural arts; and the level of income inequality (the GINI coefficient). Raw data for these measures and their sources are given in Web Appendix 3.

\section{STATISTICAL ANALYSIS}

The statistical analysis proceeds in three stages. First, I estimate the association between class identity and cultural practice across all 30 countries or regions using a linear multilevel model with random intercepts to test whether, on average, people that identify as middle-class consume more highbrow culture than those who identify as working-class (Gelman and Hill 2007).

Next, I explore whether this association varies across countries by estimating a series of 30 OLS regression models - one for each country or region - and then visualising the coefficients (Bryan and Jenkins 2016). I also plot these coefficients in relation to the proportion of people who identify as working-class.

Then, I test - again, using a multi-level, linear regression model - whether the proportion of people who identify as working-class at the society level (which has been mean-centered) is associated with highbrow consumption and whether this measure of the popularity of working- 
class identities is associated with less highbrow consumption among people who identify as middle-class. Here country-specific random intercepts are re-introduced into the model along with a measure of the proportion of people who identify as working-class. Then, I include a cross-level interaction between the proportion of people who identify as working-class and class identity, testing whether the association between highbrow consumption and class identity changes given how widespread working-class identities are within that society. Standard errors are clustered at the country-level for all models.

\section{RESULTS}

\section{MIDDLE-CLASS IDENTIFICATION IS POSITIVELY ASSOCIATED WITH HIGHBROW CULTURE}

I begin the analysis by exploring whether, on average, people who identify as 'middle-class' are more active consumers of highbrow culture. ${ }^{9}$ Specifically, in table 1, I find across all countries and regions, middle-class identification is positively associated with the index of cultural practice. People who identify as middle-class score 0.37 points higher (95\% CI: 0.35 to 0.39 ) than people who identify as working-class. This association is not removed after other individuallevel control variables are included in the model. Middle-class identification remains positively associated with cultural practice ( $\beta=0.17,95 \% \mathrm{CI}$ : 0.15 to 0.19$)$. To put the magnitude of this association into context, I compare it with the coefficients for labour market position (see Web Appendix 4). The difference in cultural practice between working-class identifiers and middle-class identifiers is approximately one-half of the magnitude of the difference between those in professional and managerial occupations and those in routine manual occupations. Class identities are - like class position - closely tied to cultural practice.

Table 1: Individual level predictors of highbrow consumption across 30 countries or regions

\begin{tabular}{|c|c|c|c|c|c|}
\hline & \multicolumn{5}{|c|}{ Highbrow consumption } \\
\hline & (1) & (2) & (3) & (4) & (5) \\
\hline \multicolumn{6}{|l|}{ Social class identification } \\
\hline \\
\hline \multirow[t]{2}{*}{ Middle- or Higher class } & & $0.37^{* * *}$ & $0.37^{* * *}$ & $0.18^{* * *}$ & $0.17^{* * *}$ \\
\hline & & $(0.010)$ & $(0.010)$ & $(0.011)$ & $(0.011)$ \\
\hline \multirow[t]{2}{*}{ Not reported } & & $0.15^{* * *}$ & $0.15^{* * *}$ & $0.056^{*}$ & $0.051^{*}$ \\
\hline & & $(0.024)$ & $(0.024)$ & $(0.023)$ & $(0.023)$ \\
\hline \multirow[t]{2}{*}{ Age } & & & $0.0050^{* * *}$ & $0.017^{* * *}$ & $0.017^{* * *}$ \\
\hline & & & $(0.0014)$ & $(0.0016)$ & $(0.0017)$ \\
\hline Female & & & $0.13^{* * *}$ & $0.16^{* * *}$ & $0.16^{* * *}$ \\
\hline
\end{tabular}

\footnotetext{
${ }^{9}$ Initially, I estimate an empty model, including only the country-level random intercepts (Table 1 ). In this empty model, the variance at the country-level is 0.086 and the variance at the individual-level is 0.64 . This results in an intraclass correlation of $\rho=0.12$, which indicates that around 12 percent of the variation in cultural consumption is due to the country in which people live while individual-level variation explains the rest. This is similar to the values of $p$ observed in other studies (Immerzeel and van Tubergen 2013).
} 
$($ Male $=0)$

Number of years of education

Labour market position

(baseline $=$ Routine manual)

Household

Student

Unemployed

Retired

Routine non-manual

Self-employed

Lower professional

Professional and managerial

Marital status

$(0=$ Unmarried $)$

Married or partnered

Divorced or separated

Widowed

Type of community

( 0 = Rural)

Small or medium town $\begin{array}{ccc}(0.0094) & (0.0094) & (0.0096) \\ & 0.054^{* * *} & 0.052^{* * *} \\ & (0.0014) & (0.0015)\end{array}$

$\begin{array}{ll}-0.029 & -0.027\end{array}$

$(0.023) \quad(0.023)$

$1.05^{* * *} \quad 1.00^{* * *}$

$(0.028) \quad(0.029)$

$0.057^{* *} \quad 0.052^{* *}$

(0.020) (0.020)

$0.14^{* * *} \quad 0.14^{* * *}$

(0.020) (0.020)

$0.11^{* * *} \quad 0.098^{* * *}$

$(0.017) \quad(0.017)$

$0.068^{*} \quad 0.083^{* *}$

$(0.027) \quad(0.027)$

$0.31^{* * *} \quad 0.30^{* * *}$

(0.024) (0.024)

$0.29^{* * *} \quad 0.28^{* * *}$

(0.022) (0.022)
$-0.022$

(0.014)

$-0.0044$

(0.021)

$-0.075^{* * *}$

(0.022)

$0.037^{* * *}$

(0.011)

$0.14^{* * *}$

$(0.012)$

\begin{tabular}{lccccc} 
Constant & $0.92^{* * *}$ & $0.73^{* * *}$ & $0.45^{* * *}$ & $-0.48^{* * *}$ & $-0.50^{* * *}$ \\
& $(0.054)$ & $(0.049)$ & $(0.060)$ & $(0.060)$ & $(0.062)$ \\
\hline Variance of the random & 0.086 & 0.069 & 0.071 & 0.048 & 0.050 \\
intercepts & $(0.019)$ & $(0.018)$ & $(0.019)$ & $(0.013)$ & $(0.013)$ \\
Variance of the individual & 0.64 & 0.61 & 0.60 & 0.54 & 0.54 \\
-level residuals & $(0.005)$ & $(0.005)$ & $(0.005)$ & $(0.005)$ & $(0.005)$ \\
\hline$N$ & 27555 & 27555 & 27555 & 26966 & 26480 \\
Regions & 30 & 30 & 30 & 30 & 30 \\
\hline
\end{tabular}


Notes: ${ }^{*} \mathrm{p}<0.05,{ }^{* *} \mathrm{p}<0.01,{ }^{* * *} \mathrm{p}<0.001$. Standard errors are in parenthesis. Model also

adjusts for age-squared. Standard errors in parentheses and are clustered at the country-level.

However, this single regression coefficient potentially obscures important differences between countries in the relationship between middle-class identification and highbrow culture. To unpack this variation, I estimate 30 separate regression models - one for each country or region - and plot the country-specific coefficient for middle-class identification in figure 1 (see web appendix 5 for the descriptive data behind these cross-country differences). This figure represents the degree to which there is a class structured opposition in highbrow consumption, that is the difference in highbrow consumption between middle-class and working-class identifiers (a higher number is a larger difference). Two striking observations can be taken from this graph. First, the estimate of the association between middle-class identities and highbrow culture in table 1 does indeed mask huge variation in this association across countries. The difference is largest in Belgium and the Netherlands and smallest in Malta and Finland. Second, in some countries people who identify as middle-class are no different in terms of their highbrow consumption from people in the same country who identify as working-class. In short, middle-class identification is not associated with more highbrow cultural practice in every European country (Katz-Gerro 2002).

\section{HIGHBROW CULTURE AND THE REJECTION OF MIDDLE-CLASS IDENTITIES}

One partial explanation for this variation is differences in the adoption of working-class identities within a society, which, I argue, may alter how people who identify as 'middle-class' consume highbrow culture. For example, The Netherlands is both a country with very few people who identify as working-class, as noted above, and a very large difference in highbrow consumption between people who identify as middle-class and those who identify as workingclass.

In figure 2 I plot the proportion of people who identify as working-class (x-axis) and the countryspecific regression coefficient measuring the difference in cultural practice between people who identify as middle- and working-class (previously reported in figure $1-y$-axis). There is still a negative correlation between these two variables $(r=-0.35)$. Both of these figures suggest that as the adoption of working-class identities becomes more widespread (and, by implication, more people are rejecting middle-class identities) the gap in highbrow consumption between people who identify as middle-class and those who identify as working-class declines.

A reduction in the gap in highbrow consumption between these groups could be explained in two different ways. Working-class identifiers could be consuming more highbrow activities in countries where more people identify as working-class. Or the reverse could be the case, middle-class identifiers may consume fewer highbrow activities in countries where workingclass identification is the norm. A brief look at the association the proportion of people who identify as working-class and the average number of highbrow activities consumed by respondents in each country is more consistent with the second explanation (see figure 3 ). In countries with high levels of working-class identification highbrow consumption is, on average, much 
Figure 1: Association between social class identification and highbrow consumption

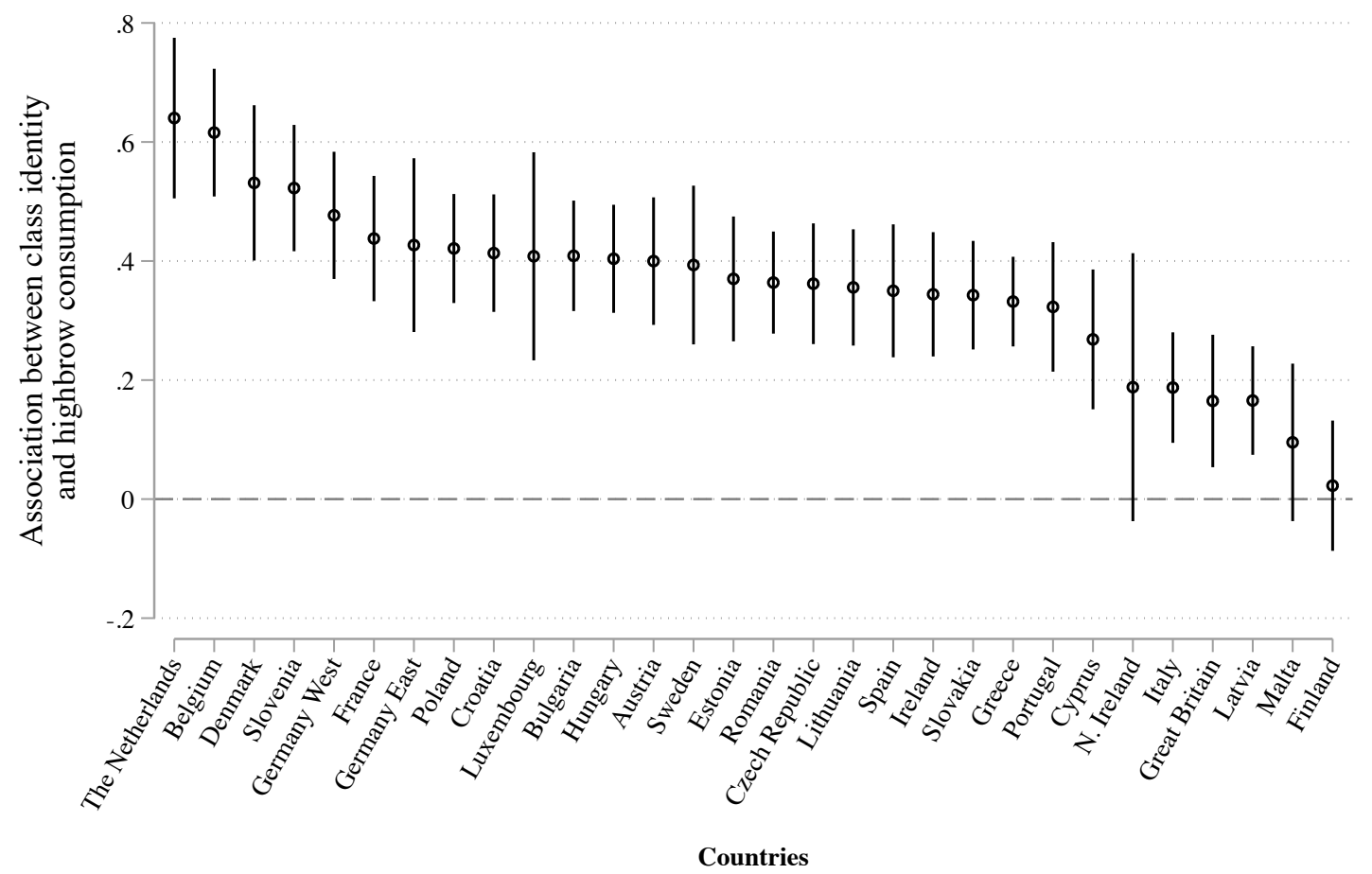

Notes: Each country specific estimate is derived from a separate model which regresses highbrow consumption on self-reported social class position, age and gender. The point estimate represents that coefficient of the association between self-reported social class and the breadth and intensity of highbrow consumption. Higher numbers imply a greater difference in highbrow consumption between middleand working-class identifiers. Vertical lines are $95 \%$ confidence intervals.

lower $(r=-0.59)$. Viewed together, these figures indicate that the gap between middle-class identifiers and working-class identifiers declines in countries with high-levels of workingclass identification because the middle-classes reject highbrow consumption in those contexts.

To model these relationships more formally, I re-estimate model 5 from table 1 but now introduce a country-level predictor (the proportion of people who identify as working-class) into the multilevel regression model. This model tests whether country-level patterns of workingclass identification is associated with patterns of highbrow consumption (Table 2). I find that, on average, people are less engaged in highbrow culture in countries where more people describe themselves as working-class. What is particularly striking, however, is that this relationship holds even after accounting for class identities at the individual level. This suggests that changes in highbrow consumption are not solely due to compositional differences between countries in the number of working-class identifiers. Another explanation is needed.

Table 2: Association between national-level class identification and highbrow 
consumption, across 30 regions

\begin{tabular}{lcc}
\hline \hline & \multicolumn{2}{c}{ Highbrow consumption } \\
& $(1)$ & $(2)$ \\
\hline Individual covariates & $\mathrm{X}$ & $\mathrm{X}$ \\
Proportion of people who view & $-0.0074^{* *}$ & $-0.0061^{*}$ \\
themselves as working class & $(0.0027)$ & $(0.0027)$ \\
Social class identification $(0=$ Working-class) & & \\
Middle- or Higher class & & $0.17^{* *}$ \\
& & $(0.011)$ \\
Not reported & & $0.051^{*}$ \\
& & $(0.023)$ \\
Constant & $-0.48^{* *}$ & $-0.53^{* *}$ \\
& $(0.062)$ & $(0.062)$ \\
\hline Variance of the random intercepts & 0.042 & 0.043 \\
Variance of the individual-level residuals & $(0.011)$ & $(0.011)$ \\
& 0.54 & 0.54 \\
\hline Observations & $(0.005)$ & $(0.005)$ \\
Regions & 26487 & 26487 \\
\hline \hline
\end{tabular}

Notes: ${ }^{*} \mathrm{p}<0.05,{ }^{* *} \mathrm{p}<0.01$. Standard errors are in parenthesis. Model also adjusts for age, gender, age-squared, education, labour market status, marital status, and community size. Standard errors in parentheses and are clustered at the country-level.

To explore this relationship further, I next introduce a cross-level interaction term, which examines whether the degree of working-class identification (or middle-class dis-identification) changes the relationship between individual-level class identification and highbrow consumption (see Model 2: Table 2) (Bryan and Jenkins 2016). This cross-level interaction is strongly associated with highbrow consumption. High levels of working-class identification remain negatively associated with highbrow consumption. In contrast, the interaction term between the degree of working-class identification and individual-level class identification is negative $(\beta=-0.0029,95 \%$ CI: -.0015 to $-.0044, p<0.001)$.

To visualise this relationship, I plot the predicted level of highbrow cultural practice for people who identify as middle- and working-class given different levels of working-class identification at the country-level (Figure 4). As shown in the figure, highbrow consumption is lower in countries where working-class identities are more common, both for people who identify as middle-class and those who identify as working-class. There is one crucial difference, however; the reduction in highbrow consumption is greatest among those who identify as middleclass. In countries where the adoption of working-class identities is widespread, the 'class structured opposition' in highbrow culture is diminished; that is, middle class consumption of highbrow culture is far less distinctive.

But, do these associations matter substantively? To explore this, I re-estimate the models using a binary measure of highbrow consumption as the dependent variable, comparing those who 
Figure 2: Working-class identification is associated with cultural practice

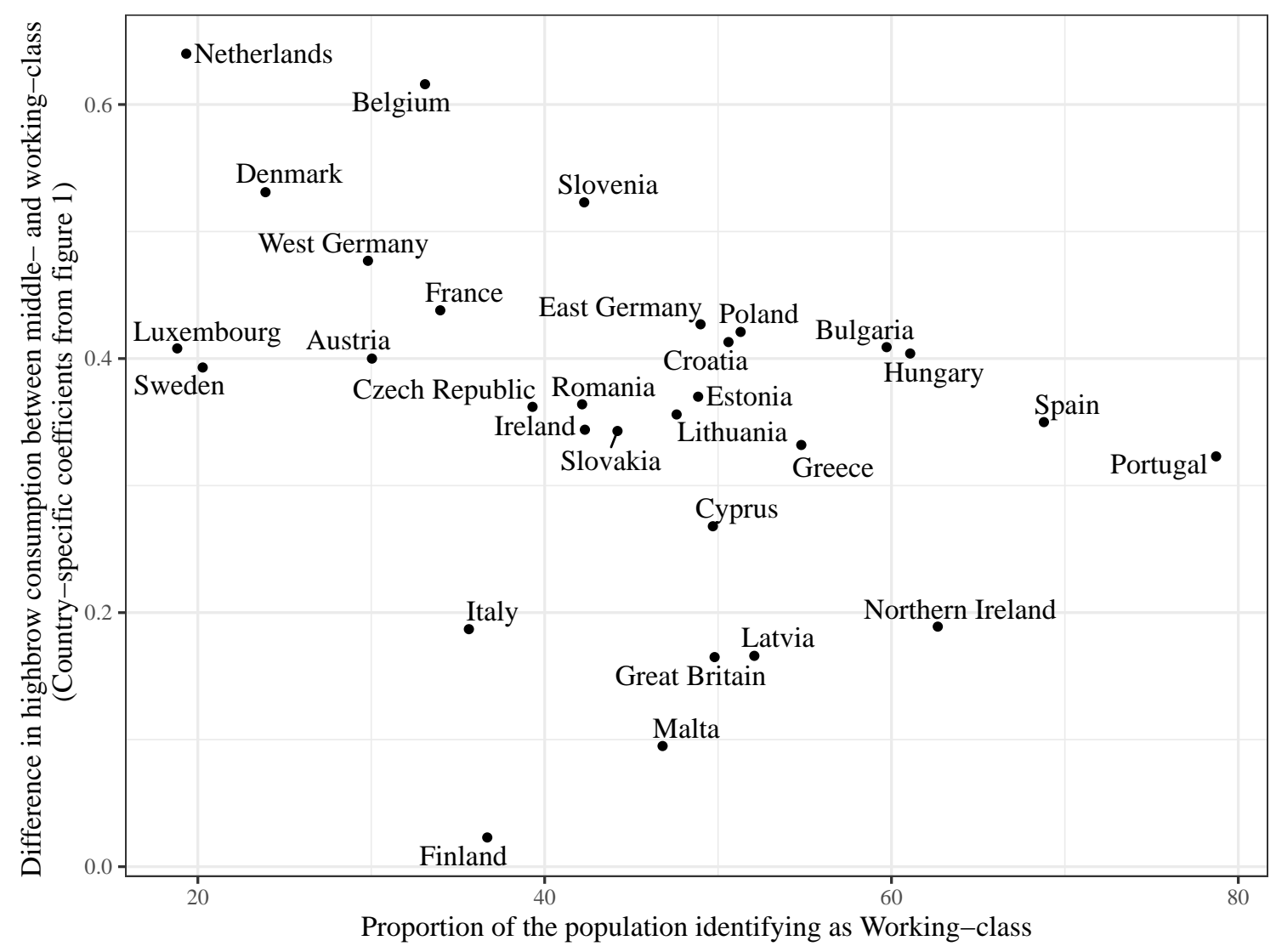

have strong or intense highbrow consumption with those who have medium or low highbrow consumption. In this scenario, in countries with very low levels of working-class identification $(\sim 30 \%)$, middle-class identifiers are around 10 percentage points more likely to be strong highbrow consumers. Whereas, in countries with high levels of working-class identification ( $\sim 60 \%)$, middle-class identifiers are 3.6 percentage points more likely to be strong highbrow consumers (and this difference is no longer statistically significant at the $\alpha=0.05$ level). Of course, these results do not suggest class identity is the most important driver of highbrow consumption, but they indicate that these associations are non-trivial.

One explanation for these results may be differences in who identifies as middle- and workingclass across countries. If countries use different class identities to locate themselves even though they are working in the same type of occupation (e.g., professional and managerial) then these results may be explained by inconsistencies in how the question is answered. To test this possibility in more detail, I select two tracer groups that are stable across countries, namely: 1) individuals who are professionals who also identify as middle-class and 2) individuals who work in routine manual occupations who identify as working-class. Selecting these two groups, I can explore whether the same decline in highbrow culture is still observed even after removing 
Figure 3: The average level of highbrow consumption is higher in countries where there are fewer people who identify as working-class

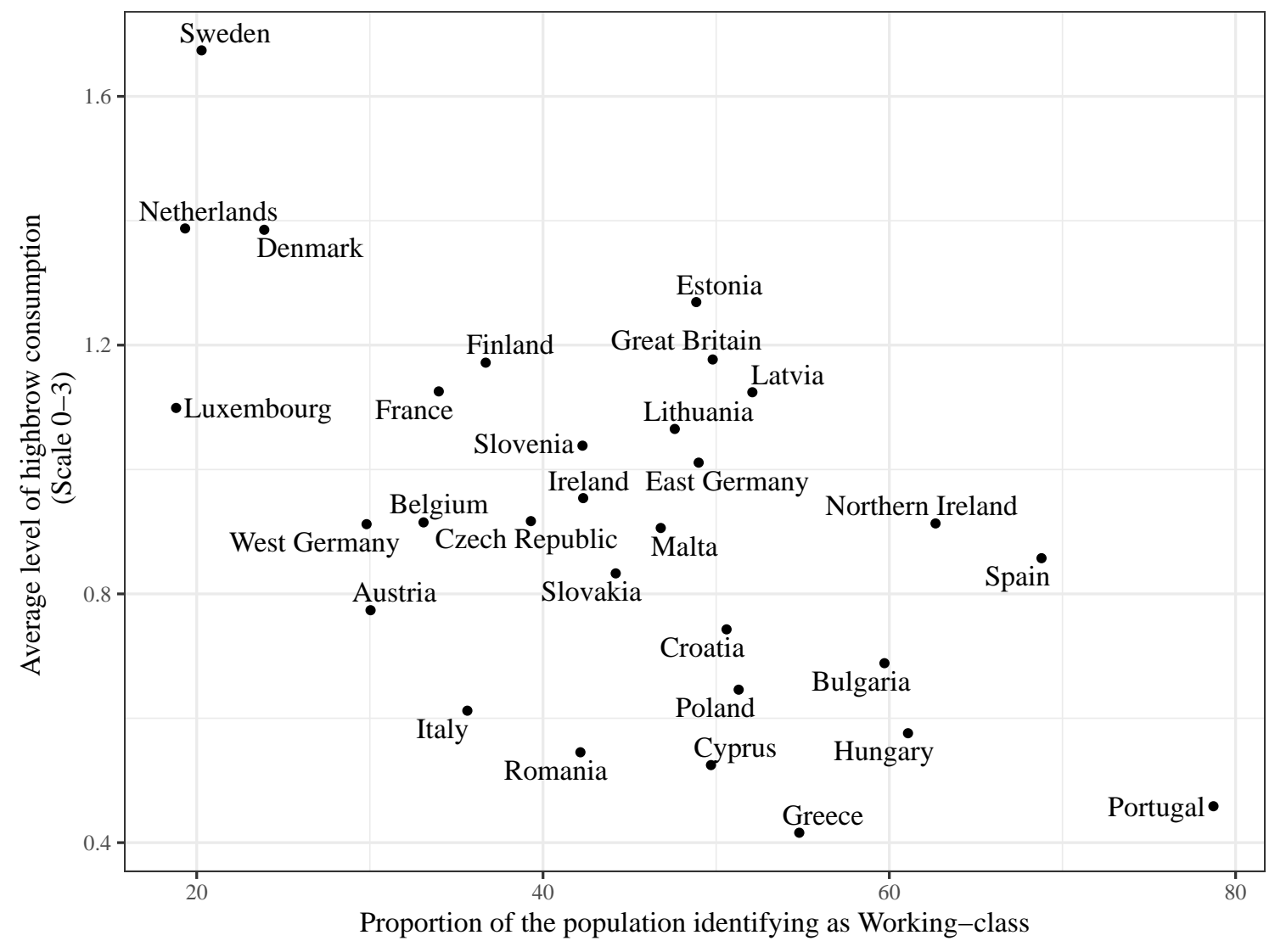

country-specific differences in how certain occupations locate themselves in the class hierarchy. Once again, highbrow culture declines in both groups but it declines fastest among the professionals who identify as middle-class so that at high levels of working-class identification there is no clear difference in the highbrow consumption between these two groups (Web Appendix 6).

Digging deeper, I explore the same question but now with just two separate activities, comparing the association with visiting galleries and watching a cultural programme on TV or listening to a cultural programme on the radio. Here, I follow the logic of DiMaggio and Mukhtar (2004), who argue that if the status of highbrow culture has declined then we would expect to see more marked declines in consumption of high-culture events (such as visiting galleries) than those with more mass appeal (such as cultural programmes on TV or radio). Consistent with their argument, it is only visiting galleries that is associated with differences in the popularity of working-class identities, and not activities focused on the television or radio (Table $3)$.

Table 3: Association between national-level class identification and both galleries and TV, 


\begin{tabular}{lcc} 
across 30 regions & & \\
\hline \hline & Gallery & TV \\
& $(1)$ & $(2)$ \\
\hline Individual covariates & $\mathrm{X}$ & $\mathrm{X}$ \\
Proportion of people who view themselves as working class & -0.0041 & -0.0040 \\
& $(0.0022)$ & $(0.0039)$ \\
Social class identification $(0=$ Working-class $)$ & & \\
Middle- or Higher class & $0.38^{* *}$ & $0.20^{* *}$ \\
& $(0.037)$ & $(0.057)$ \\
Not reported & $0.32^{* *}$ & 0.14 \\
& $(0.088)$ & $(0.14)$ \\
\% Working class $\times$ individual identifies with middle- or higher-class & $-0.0042^{* *}$ & -0.0011 \\
& $(0.00079)$ & $(0.0012)$ \\
\% Working class $\times$ individual does not identify with social class & $-0.0050^{* *}$ & -0.0042 \\
& $(0.0018)$ & $(0.0028)$ \\
Constant & $-0.35^{* *}$ & 0.11 \\
& $(0.11)$ & $(0.20)$ \\
\hline Variance of the random intercepts & 0.027 & 0.086 \\
Variance of the individual-level residuals & $(0.007)$ & $(0.023)$ \\
& 0.58 & 1.39 \\
\hline Observations & $(0.005)$ & $(0.012)$ \\
\hline Regions & 26487 & 26487 \\
\hline
\end{tabular}

Notes: ${ }^{*} \mathrm{p}<0.05,{ }^{* *} \mathrm{p}<0.01$. Model also adjusts for age, gender, age-squared, education, labour market status, marital status, and community size. Standard errors in parentheses and are clustered at the country-level.

Taken together, these findings suggest that the widespread adoption of working-class identities within a society alters how people who identify as 'middle-class' consume highbrow culture, so that in countries where working-class identities are most common there is a rejection of highbrow culture, even among those people who still identify as middle-class.

\section{ROBUSTNESS TESTS}

To ensure these findings are not driven by model specification, I conduct a series of sensitivity tests. These are described in detail in web appendices 7-14 but include: using alternative dependent and independent variables, including other country-level controls (such as GNI, GINI, social mobility, and proportion of the labour force employed in the service class), using a bootstrap procedure (which repeatedly re-estimates the main model but sequentially removes one country from each model) to test whether the interaction terms vary after excluding any specific country, and using different kinds of weights. In each case, the results are consistent with the main findings reported above. 
Figure 4: Class identification moderates the association between class identification and active highbrow consumption

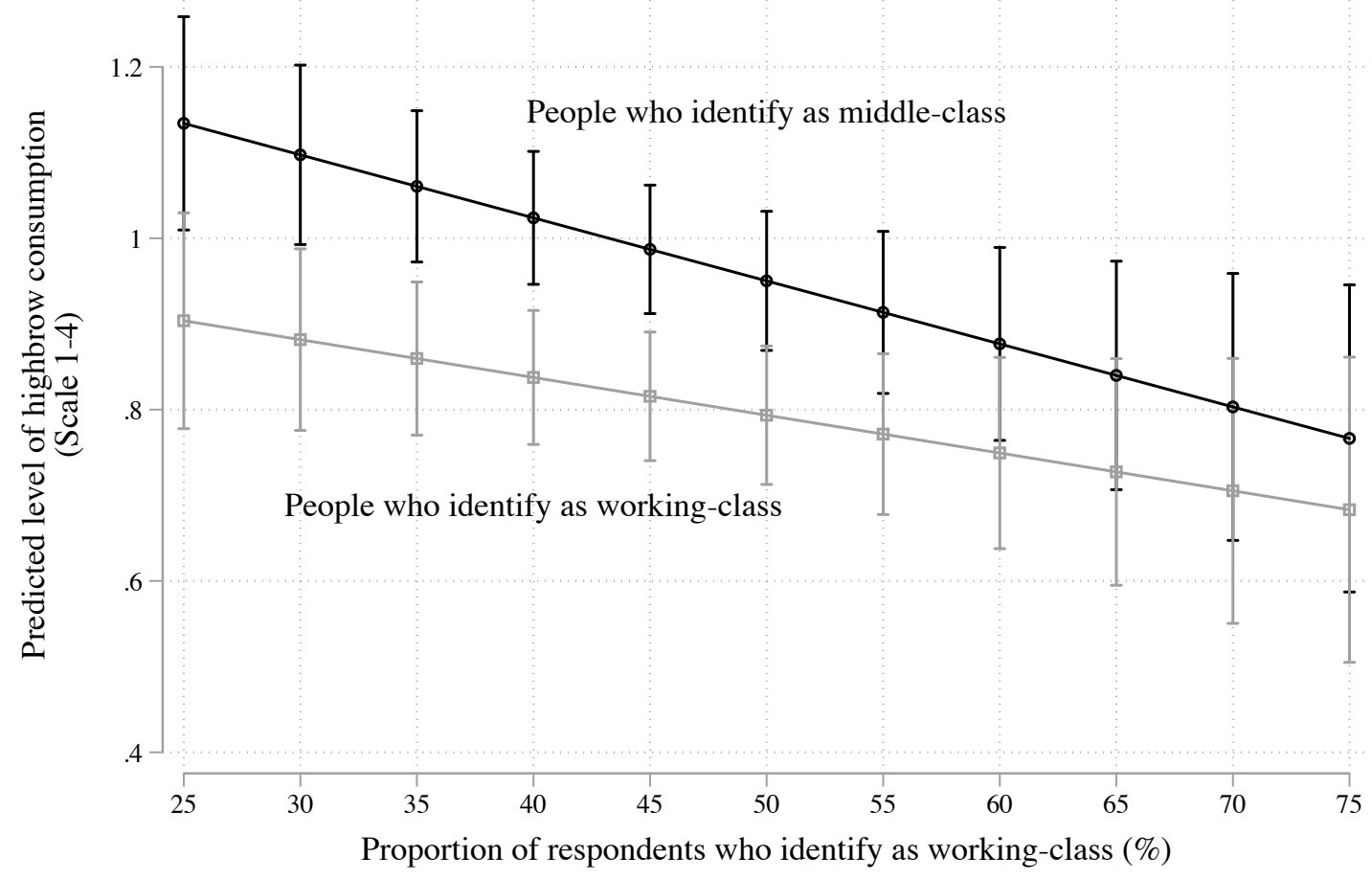

Notes: Vertical bars are $95 \%$ confidence intervals

\section{LIMITATIONS}

There are important limitations to this study. First, I use aggregate patterns of class identity to capture how people see social hierarchies and this may only capture one aspect of how people view systems of stratification. Moreover, this measure of class identity does not entirely reflect the complexity with which people describe their class identities, e.g., 'upper middle class' (Harrits and Pedersen 2018). Whilst acknowledging these limitations, there is consistency in the results when using alternative measures of the social hierarchy, suggesting these aggregate indicators are independently measuring something similar about how large groups of people understand what it means to be middle-class (according one measure) or in a higher position in society (according to the other measure). What is less clear, however, is how the results might change if a more refined measure of class identity had been used in this wave of the Eurobarometer. More nuanced measures of class identity may offer additional insight into how class identities are associated with highbrow culture across countries and so future work will need to explore this issue in more detail.

Second, questions about class identity do not reflect the complexity and ambivalence of people's responses to such questions in interview settings (Savage et al. 2010). While this is un- 
doubtedly true, these questions are still an enactment of class position. For example, people could, but do not, reject these labels in large numbers. In fact, those who do reject these class labels appear to be quite similar to people who identify as middle-class, suggesting rejecting class labels could be a middle-class performance of the ambivalence they feel about their high status position.

Third, this survey does not contain a direct measure of income. It is therefore possible that observed associations are due to residual confounding created by the absence of these variables. However, once education and occupation have been taken into account, income is not the strongest predictor of cultural consumption and so the degree of residual confounding here is likely small (Chan 2010).

\section{DISCUSSION}

This article explores the relationship between class identity and participation in highbrow culture across 30 countries and regions with a view to understanding whether consumption of traditional and/or highbrow cultural practices is always characterised by a 'class structured opposition'. Two key findings emerge from this analysis. First, class identity - even after accounting for education and labour market position - is associated with highbrow consumption. People who identify as middle-class are more likely, on average, to consume highbrow culture than those who identify as working-class. Second, looking more closely at specific countries or regions, it becomes clear that the strength of the association between highbrow consumption and identifying as middle-class is not the same everywhere. When situated in the context of class identities, participation in highbrow culture does not always differentiate class positions.

This variation across countries adds new insight to our understanding of whether and how highbrow consumption marks class position and its connection to cultural capital (DiMaggio and Mukhtar 2004). At a glance, the absence of a 'class structured opposition' in highbrow culture might imply that such activities have a weaker connection to performing class distinction in European countries with high levels of working-class identification, such as the UK, Portugal, and Finland; or, more provocatively, that 'the exclusive respect traditionally accorded to "highbrow" cultural pursuits has largely dissolved' in these contexts (Lareau and Weininger 2003). However, we should be cautious about accepting this position based solely on these cross-country models because qualitative work in some of those countries where differences in highbrow consumption are smallest, such as Finland, have documented the continued importance of highbrow culture to class distinctions (Purhonen, Gronow, and Rahkonen 2011).

Another possible reading of these results, one which is more consistent with this qualitative work, relies on the distinction between practice and disposition, and the relationship between them. Dispositions can foster distinctions in what cultural practices people consume and this

may explain why the middle-classes, who embody the logic of particular dispositions, are more drawn to specific cultural objects than the working-classes, who embody quite different dispositions (Bourdieu 1984). Dispositions can, however, function in another way too; by creating 
differences in how people consume cultural objects (Bennett et al. 2009). In this second sense, the same set of cultural practices may simultaneously endow separate individuals with differing degrees of cultural capital because the dispositions rather than the practices denote distinction. In other words, it is not what you consume but how you consume cultural products that can be converted into cultural capital (Lizardo and Skiles 2016a). In this vein, then, the absence of a 'class structured opposition' in highbrow culture may be symptomatic of differences in how cultural capital functions in separate contexts (Lamont 1992). To be more precise, in countries where there is widespread adoption of middle-class identities (where there are clear distinctions in highbrow consumption between those who identify as working- and middle-class), cultural capital may be acquired through participating in specific sets of practices. However, in countries where there is widespread rejection of middle-class identities (where there are no clear distinctions in terms of highbrow consumption between those who identify as workingand middle-class), cultural capital may be acquired through the manner in which you consume cultural objects. In short, how you consume may matter more for cultural capital in countries where working-class identities dominate.

These reflections on why highbrow practices seem to mark class distinctions more clearly in some contexts rather than others go beyond what can be firmly establish from these data alone; but they are grounded in both survey, qualitative, and experimental evidence, all of which point in a similar direction. These earlier studies all suggest people's expressed cultural tastes are relational, contingent on the practices and perceptions of others. Lizardo and Skiles (2016b), for example, document how genres and practices 'acquire and communicate status' because of the dominant characteristics among those assumed to be the audience of such cultural objects. In other words, if I assume the 'wrong' people - whoever they are - consume highbrow culture then I will be more likely to reject such cultural objects. This process also plays out in experimental settings. British people downplayed their more highbrow tastes when they were exposed to a working-class vignette who they imagined would 'dislike' highbrow culture (Reeves et al. 2015). Similarly, high status Americans expressed positive preferences for lowbrow culture when they felt 'insecure' about their high-status position (Hahl et al. 2017). All three of these studies highlight how highbrow culture can be deployed as a form of position-taking with respect to others (Lizardo and Skiles 2016b). These studies then also potentially provide a mechanism explaining these findings. In countries where the vast majority of people identify as 'working-class', with all that self-designation entails, people who continue to identify as 'middle-class' may alter their cultural practices in response to those who they imagine will dislike highbrow culture. They may even feel 'insecure' about their status position because they risk being labelled a 'snob' if they also consume highbrow culture, social criticisms which are particularly potent in some settings (Jarness and Friedman 2017). More cross-national qualitative work will, of course, be needed to uncover whether these processes are at play across these European settings, but the patterns documented here are consistent with survey data and small-scale experimental studies which stress the relational nature of highbrow consumption.

Beyond debates about cultural capital, these findings also assert the importance of re-incorporating class identities into our theories of the social stratification of culture. This move is especially important because Bourdieu's (1984) account of social class suggests class identities have little 
part to play in understanding social stratification. ${ }^{10}$ However, re-incorporating class identity into work on class and culture will allow sociologists to elucidate the 'cultural politics of class' (Savage et al. 2010), to observe the sites of class-making and the places where classificatory struggles occur (Tyler 2015). The symbolic values of class identity and cultural consumption may be more malleable than other forms of social stratification and so by focusing on class and culture it becomes possible to effectively register the distinctiveness of place in how these processes play out (Reeves et al. 2015). One implication which flows from this analysis suggests claiming a middle-class identity and, tied to this, participating in highbrow cultural activities are not straightforwardly convertible into cultural capital in every country. To be clear, this does not negate Bourdieu's claim that the field of power is structured according to the volume and composition of capitals (Flemmen et al. 2017); but it does suggest that whether certain forms of cultural consumption can be deployed as cultural capital is contingent on the context in which those practices are embedded (Krause 2018).

\footnotetext{
${ }^{10}$ Bourdieu intentionally ignored class identity because his theory tried to supersede the distinction between objective and subjective class positions that had animated much class analysis (Savage, Silva, and Warde 2010). Yet, his later work reflects a more nuanced position on class identities. In What makes a Social Class? (1987) Bourdieu recognises that while class identities may be viewed as representing certain shared 'objective probabilities', the boundaries of class identities - as drawn across the social space - are not fixed and must be actively constructed. Importantly, the process of generating class identities - 'the symbolic work of fabricating groups' (Bourdieu 1987) - entails 'classificatory struggles' over what is socially valuable to a particular community (see also Tyler 2015). The rejection of middle-class identities is one manifestation of these 'classificatory struggles'.
} 
Acknowledgments I would like to thank Sam Friedman, Magne Flemmen and Robert de Vries for helpful comments on earlier versions of this paper. I would also like to acknowledge the reviewers and the editor at Poetics whose comments have helped improve the paper.

Funding While conducting this research, I have been supported by Joseph Rowntree Foundation, which is gratefully acknowledged. Views expressed in the article do not necessarily reaect the ofacial views of the funding institutions.

Aaron Reeves is Associate Professor in the Department of Social Policy and Intervention at the University of Oxford. His research is focused on understanding the causes and consequences of social, economic, and cultural inequality across countries. 


\section{REFERENCES}

Bennett, Tony, Mike Savage, E. Silva, Alan Warde, M. Gayo-Cal, and D. Wright. 2009. Culture, Class, Distinction. London: Routledge.

Bottero, W. 2004. "Class Identities and the Identity of Class." Sociology-the Journal of the British Sociological Association 38(5):985-1003.

Bourdieu, Pierre. 1984. Distinction: a social critique of the judgement of taste. London: Routledge \& Kegan Paul.

Bourdieu, Pierre. 1987. "What Makes a Social Class? On The Theoretical and Practical Existence Of Groups.” Berkeley Journal of Sociology 32:1-17.

Breen, Richard and Jan O. Jonsson. 2005. "Inequality of Opportunity in Comparative Perspective: Recent Research on Educational Attainment and Social Mobility." Annual Review of Sociology 31(1):223-43.

Bryan, Mark L. and Stephen P. Jenkins. 2016. "Multilevel Modelling of Country Effects: A Cautionary Tale." European Sociological Review 32(1):3-22.

Chan, Tak Wing. 2010. Social Status and Cultural Consumption. Cambridge: Cambridge University Press.

Chan, Tak Wing. 2013. "Understanding Cultural Omnivores: Social and Political Attitudes." Oxford Sociology Working Papers.

Daloz, Jean-Pascal. 2007. "Political Elites and Conspicuous Modesty: Norway, Sweden, Finland in Comparative Perspective." Comparative Social Research 23(Comparative Studies of Social and Political Elites):171-210.

Devine, Fiona and Mike Savage. 2005. “The Cultural Turn, Sociology and Class Analysis.” Pp. 1-23 in Rethinking Class: Cultures, Identities \& Lifestyles, edited by F. Devine, M. Savage, J. Scott, and R. Crompton. Basingstoke: Palgarve MacMillan.

DiMaggio, P. 1987. “Classification in Art.” American Sociological Review 52(4):440-55.

DiMaggio, P. and T. Mukhtar. 2004. "Arts Participation as Cultural Capital in the United States, 1982-2002: Signs of Decline?” Poetics 32(2):169-94.

Edelmann, Achim and Stephen Vaisey. 2014. "Cultural Resources and Cultural Distinction in Networks." Poetics 46:22-37.

van Eijk, Gwen. 2013. "Hostile to Hierarchy? Individuality, Equality and Moral Boundaries in Dutch Class Talk." Sociology 47(3):526-41. 
European Commission. 2013. Eurobarometer 79.2: Internal Market, Cultural Activities, NonUrban Road Use, Science and Technology, and Undeclared Work and Tax Fraud, April-May 2013. Cologne, Germany: GESIS.

Evans, Geoffrey and Colin Mills. 1999. "Are There Classes in Post-Communist Societies? A New Approach to Identifying Class Structure." Sociology 33(1):23-46.

Evans, Geoffrey and James Tilley. 2012. "How Parties Shape Class Politics: Explaining the Decline of the Class Basis of Party Support.” British Journal of Political Science 42(1):137-61.

Falk, Martin and Tally Katz-Gerro. 2016. "Cultural Participation in Europe: Can We Identify Common Determinants?” Journal of Cultural Economics 40(2):127-62.

Flemmen, Magne, Vegard Jarness, and Lennart Rosenlund. 2017. "Social Space and Cultural Class Divisions: The Forms of Capital and Contemporary Lifestyle Differentiation." The British Journal of Sociology.

Gelman, Andrew and Jennifer Hill. 2007. Data Analysis Using Regression and Multilevel/Hierarchical Models. Cambridge: Cambridge University Press.

Gullestad, Marianne. 1985. Kitchen-Table Society: Case Study of the Family Life and Friendships of Young Working-Class Mothers in Norway. Oslo : Irvington-on-Hudson, N.Y: Universitetsforlaget.

Hahl, Oliver, Ezra W. Zuckerman, and Minjae Kim. 2017. "Why Elites Love Authentic Lowbrow Culture: Overcoming High-Status Denigration with Outsider Art." American Sociological Review 82(4):828-56.

Harrits, Gitte Sommer and Helene Helboe Pedersen. 2018. "Class Categories and the Subjective Dimension of Class: The Case of Denmark." The British Journal of Sociology 69(1):67-98.

Hek, Margriet and Gerbert Kraaykamp. 2013. "Cultural Consumption across Countries: A Multi-Level Analysis of Social Inequality in Highbrow Culture in Europe." Poetics 41:323341.

Hout, Michael., ed. 2008. How Class Works in Popular Conception: Most Americans Identify with the Class Their Income, Occupation, and Education Implies for Them. New York: Russell Sage Foundation.

Immerzeel, Tim and Frank van Tubergen. 2013. "Religion as Reassurance? Testing the Insecurity Theory in 26 European Countries.” European Sociological Review 29(2):359-72.

Jarness, Vegard and Magne Paalgard Flemmen. 2019. "A Struggle on Two Fronts: Boundary Drawing in the Lower Region of the Social Space and the Symbolic Market for 'down-toEarthness.” The British Journal of Sociology 70(1):166-89. 
Jarness, Vegard and Sam Friedman. 2017. “I'm Not a Snob, But...': Class Boundaries and the Downplaying of Difference." Poetics 61(Supplement C):14-25.

Kantola, Anu and Hanna Kuusela. 2018. "Wealth Elite Moralities: Wealthy Entrepreneurs' Moral Boundaries.” Sociology 0038038518768175.

Karlsson, Lena. 2005. "Klasstillhörighetens subjektiva dimension : klassidentitet, sociala attityder och fritidsvanor."

Karlsson, Lena. 2017. "Self-Placement in the Social Structure of Sweden: The Relationship between Class Identification and Subjective Social Placement." Critical Sociology 43(7-8):104561.

Katz-Gerro, T. 2002. "Highbrow Cultural Consumption and Class Distinction in Italy, Israel, West Germany, Sweden, and the United States." Social Forces 81(1):207-29.

Katz-Gerro, T. and O. Sullivan. 2010. "Voracious Cultural Consumption The Intertwining of Gender and Social Status.” Time \& Society 19(2):193-219.

Katz-Gerro, Tally. 2011. "Cross-National Cultural Consumption Research: Inspirations and Disillusions.” Kolner Zeitschrift Fur Soziologie Und Sozialpsychologie 51:339-360.

Krause, Monika. 2018. "How Fields Vary.” The British Journal of Sociology 69(1):3-22.

Lagaert, Susan and Henk Roose. 2018. "Gender and Highbrow Cultural Participation in Europe: The Effect of Societal Gender Equality and Development." International Journal of Comparative Sociology 59(1):44-68.

Lamont, Miche le. 1992. Money, Morals, and Manners : The Culture of the French and American Upper-Middle Class. Chicago ; London: University of Chicago Press.

Lamont, Michele and Virag Molnar. 2002. "The Study of Boundaries in the Social Sciences." Annual Review of Sociology 28(1):167-95.

Lareau, Annette and Elliot B. Weininger. 2003. "Cultural Capital in Educational Research: A Critical Assessment." Theory and Society 32(5/6):567-606.

Larsen, Håkon. 2016. Performing Legitimacy: Studies in High Culture and the Public Sphere. Springer. Levine, Lawrence W. 1988. Highbrow. Cambridge, Mass. ; London: Harvard University Press.

Lizardo, O. 2006a. "How Cultural Tastes Shape Personal Networks." American Sociological Review 71:778-807.

Lizardo, O. 2006b. “The Puzzle of Women’s ‘Highbrow’ Culture Consumption: Integrating 
Gender and Work into Bourdieu's Class Theory of Taste." Poetics 34(1):1-23.

Lizardo, Omar and Sara Skiles. 2016a. "After Omnivorousness: Is Bourdieu Still Relevant?'” in Handbook of the Sociology of Art and Culture, edited by L. Hanquinet and M. Savage. London: Routledge.

Lizardo, Omar and Sara Skiles. 2016b. "Cultural Objects as Prisms: Perceived Audience Composition of Musical Genres as a Resource for Symbolic Exclusion.” Socius 2:2378023116641695.

Ljunggren, Jørn. 2017. "Elitist Egalitarianism: Negotiating Identity in the Norwegian Cultural Elite." Sociology 51(3):559-74.

Martin, John Levi and Ben Merriman. 2015. "A Social Aesthetics as a General Cultural Sociology?” in Routledge International Handbook of the Sociology of Art and Culture. London: Routledge.

Pape, S., J. Rossel, and H. Solga. 2012. “Do We See Class Membership and How?” Poetics 40(4):317-36.

Prieur, Annick, Lennart Rosenlund, and Jakob Skjott-Larsen. 2008. "Cultural Capital Today: A Case Study from Denmark.” Poetics 36(1):45-71.

Prieur, Annick and Mike Savage. 2013. "Emerging Forms of Cultural Capital." European Societies 15(2):246-67.

Purhonen, Semi, Jukka Gronow, and Keijo Rahkonen. 2011. "Highbrow Culture in Finland: Knowledge, Taste and Participation.” Acta Sociologica 54(4):385-402.

Reeves, Aaron. 2016. "Age-Period-Cohort and Cultural Engagement." in Routledge International Handbook of the Sociology of Art and Culture. Oxford: Routledge.

Reeves, Aaron, Emily Gilbert, and Daniel Holman. 2015. "Class Dis-Identification, Cultural Stereotypes, and Music Preferences: Experimental Evidence from the UK." Poetics 50:44-61.

Reeves, Aaron and Robert de Vries. 2018. "Can Cultural Consumption Increase Future Earnings? Exploring the Economic Returns to Cultural Capital." The British Journal of Sociology.

Savage, M., G. Bagnall, and B. Longhurst. 2001. "Ordinary, Ambivalent and Defensive: Class Identities in the Northwest of England." Sociology-the Journal of the British Sociological Association 35(4):875-92.

Savage, Mike, Elizabeth Silva, and Alan Warde. 2010. "Dis-Identification and Class Identity." Pp. 60-74 in Cultural Analysis and Bourdieu's Legacy, edited by E. Silva and A. Warde. London: Routledge. 
Schneider, Silke L. 2010. "Nominal Comparability Is Not Enough: (In-)Equivalence of Construct Validity of Cross-National Measures of Educational Attainment in the European Social Survey." Research in Social Stratification and Mobility 28(3):343-57.

Skarpenes, Ove and Rune Sakslind. 2010. "Education and Egalitarianism: The Culture of the Norwegian Middle Class.” The Sociological Review 58(2):219-43.

Skeggs, Beverley. 2004. Class, Self, Culture. London: Routledge.

Sosnaud, Benjamin, David Brady, and Steven M. Frenk. 2013. "Class in Name Only: Subjective Class Identity, Objective Class Position, and Vote Choice in American Presidential Elections." Social Problems 60(1):81-99.

Tyler, Imogen. 2015. "Classificatory Struggles: Class, Culture and Inequality in Neoliberal Times.” The Sociological Review 63(2):493-511.

Upchurch, Anna. 2004. "John Maynard Keynes, the Bloomsbury Group and the Origins of the Arts Council Movement.” International Journal of Cultural Policy 10(2):203-17.

Wright, Erik Olin. 1997. Class Counts: Comparative Studies in Class Analysis. Cambridge: Cambridge University Press. 


\section{WEB APPENDIX}

Web Appendix 1: Individual level predictors of class identity across 30 regions

Web Appendix 2: Descriptive statistics for individual level covariates

Web Appendix 3: Country-level covariates included in multilevel regression models

Web Appendix 4: Standardized employment and class identity predictors of highbrow consumption across 30 regions

Web Appendix 5: Descriptive data on class composition and highbrow consumption across countries

Web Appendix 6: Association between national-level class identification and highbrow consumption, measuring number of activities participated in during the last 12 months, across 30 regions

Web Appendix 7: Association between national-level class identification and highbrow consumption among professionals who identify as middle-class and routine manual workers who identify as working-class

Web Appendix 8: Association between national-level class identification and highbrow consumption, measuring the proportion of people who consider themselves high-level, across 30 regions

Web Appendix 9: Association between national-level class identification and highbrow consumption, adjusting for country-level covariates, across 30 regions

Web Appendix 10: Association between national-level class identification and highbrow consumption, combining very similar regions, across 28 regions

Web Appendix 11: Association between national-level class identification and highbrow consumption, including only those aged 25-75 and those who are not in full-time education, across 28 regions

Web Appendix 12: Bootstrapped cross-level interaction term between identifying middleclass and the level of middle-class identification, sequentially removing one country from each model, across 30 regions.

Web Appendix 13: Association between national-level class identification and highbrow consumption, across 30 regions, with weights

Web Appendix 14: Class identification moderates the association between class identification and highbrow consumption, using weights 
WEB APPENDIX 1: INDIVIDUAL LEVEL PREDICTORS OF CLASS IDENTITY ACROSS 30 REGIONS

\begin{tabular}{|c|c|c|}
\hline \multirow[b]{2}{*}{ Covariates } & \multicolumn{2}{|c|}{$\begin{array}{c}\text { Class identitty } \\
\text { (Working-class }=\text { baseline) }\end{array}$} \\
\hline & $\begin{array}{c}\text { Middle-class } \\
\text { (1) }\end{array}$ & $\begin{array}{l}\text { Other } \\
(2)\end{array}$ \\
\hline Age & $\begin{array}{c}-0.0092^{* * *} \\
(0.0010)\end{array}$ & $\begin{array}{c}-0.0054^{* * *} \\
(0.00090)\end{array}$ \\
\hline Age squared & $\begin{array}{l}0.00011^{* * *} \\
(0.000010)\end{array}$ & $\begin{array}{r}0.000053^{* * *} \\
(0.0000089)\end{array}$ \\
\hline Female & $\begin{array}{c}0.027^{* * *} \\
(0.0058)\end{array}$ & $\begin{array}{c}0.0058 \\
(0.0051)\end{array}$ \\
\hline Years of education & $\begin{array}{l}0.034^{* * *} \\
(0.00085)\end{array}$ & $\begin{array}{l}0.0063^{* * *} \\
(0.00088)\end{array}$ \\
\hline \multicolumn{3}{|c|}{ Labour market position (baseline $=$ Routine manual) } \\
\hline Household & $\begin{array}{l}0.11^{* * *} \\
(0.014)\end{array}$ & $\begin{array}{l}0.075^{* * *} \\
(0.011)\end{array}$ \\
\hline Student & $\begin{array}{l}0.61^{* * *} \\
(0.017)\end{array}$ & $\begin{array}{l}0.19^{* * *} \\
(0.016)\end{array}$ \\
\hline Unemployed & $\begin{array}{c}0.019 \\
(0.012)\end{array}$ & $\begin{array}{l}0.058^{* * *} \\
(0.0089)\end{array}$ \\
\hline Retired & $\begin{array}{l}0.11^{* * *} \\
(0.012)\end{array}$ & $\begin{array}{l}0.049^{* * *} \\
(0.0092)\end{array}$ \\
\hline Routine non-manual & $\begin{array}{l}0.23^{* * *} \\
(0.010)\end{array}$ & $\begin{array}{l}0.034^{* * *} \\
(0.0087)\end{array}$ \\
\hline Self-employed & $\begin{array}{l}0.22^{* * *} \\
(0.016)\end{array}$ & $\begin{array}{c}0.070^{* * *} \\
(0.014)\end{array}$ \\
\hline Lower professional & $\begin{array}{l}0.34^{* * *} \\
(0.014)\end{array}$ & $\begin{array}{c}0.080^{* * *} \\
(0.018)\end{array}$ \\
\hline Professional and managerial & $\begin{array}{l}0.36^{* * *} \\
(0.013)\end{array}$ & $\begin{array}{l}0.14^{* * *} \\
(0.016)\end{array}$ \\
\hline \multicolumn{3}{|l|}{ Marital status $(0=$ Unmarried $)$} \\
\hline Married or partnered & $\begin{array}{l}0.037^{* * * *} \\
(0.0083)\end{array}$ & $\begin{array}{l}-0.016^{*} \\
(0.0073)\end{array}$ \\
\hline Divorced or separated & $\begin{array}{c}-0.047^{* * *} \\
(0.012)\end{array}$ & $\begin{array}{l}-0.0092 \\
(0.010)\end{array}$ \\
\hline Widowed & $\begin{array}{l}-0.039^{* *} \\
(0.013)\end{array}$ & $\begin{array}{l}0.0036 \\
(0.011)\end{array}$ \\
\hline \multicolumn{3}{|l|}{ Type of community ( 0 = Rural) } \\
\hline Small or medium town & $\begin{array}{l}0.040^{* * *} \\
(0.0065)\end{array}$ & $\begin{array}{c}0.0053 \\
(0.0057)\end{array}$ \\
\hline Large town or city & $\begin{array}{l}0.082^{* * *} \\
(0.0072)\end{array}$ & $\begin{array}{l}0.032^{* * *} \\
(0.0064)\end{array}$ \\
\hline
\end{tabular}




\begin{tabular}{lcc} 
Constant & $0.14^{* * *}$ & $0.10^{* * *}$ \\
& $(0.035)$ & $(0.025)$ \\
\hline Variance of the random intercepts & 0.013 & 0.0016 \\
& $(0.0035)$ & $(0.0005)$ \\
Variance of the individual-level residuals & 0.19 & 0.074 \\
& $(0.0017)$ & $(0.0009)$ \\
\hline Observations & 25385 & 12892 \\
Regions & 30 & 30 \\
\hline \hline
\end{tabular}

Notes: ${ }^{*} \mathrm{p}<0.05,{ }^{* *} \mathrm{p}<0.01$. Standard errors in parentheses and are clustered at the country-level. 
WeB APPENDIX 2: DESCRIPTIVE STATISTICS FOR INDIVIDUAL LEVEL COVARIATES

\begin{tabular}{lcccc}
\hline Variables & $\mathbf{N}$ & Mean & Min & Max \\
\hline Age & 27,563 & 48.78 & 15 & 98 \\
Female & 27,563 & 1.546 & 1 & 2 \\
Years of education & 26,973 & 7.840 & 0 & 20 \\
Unmarried & 27,095 & 0.186 & 0 & 1 \\
Married or partner & 27,095 & 0.635 & 0 & 1 \\
Divorced or separated & 27,095 & 0.0834 & 0 & 1 \\
Widowed & 27,095 & 0.0956 & 0 & 1 \\
Rural area or village & 27,541 & 0.351 & 0 & 1 \\
Small/medium-sized town & 27,541 & 0.372 & 0 & 1 \\
Large town & 27,541 & 0.277 & 0 & 1 \\
Household & 27,563 & 0.0681 & 0 & 1 \\
Student & 27,563 & 0.0766 & 0 & 1 \\
Unemployed & 27,563 & 0.0885 & 0 & 1 \\
Retired & 27,563 & 0.295 & 0 & 1 \\
Manual & 27,563 & 0.125 & 0 & 1 \\
Routine non-manual & 27,563 & 0.179 & 0 & 1 \\
Self-employed & 27,563 & 0.0362 & 0 & 1 \\
Lower professional & 27,563 & 0.0576 & 0 & 1 \\
Professional and managerial & 27,563 & 0.0743 & 0 & 1 \\
Working-class & 27,563 & 0.439 & 0 & 1 \\
Middle- and upper-class & 27,563 & 0.518 & 0 & 1 \\
Not reported & 27,563 & 0.0429 & 0 & 1 \\
\hline
\end{tabular}


WeB APPENDIX 3: COUNTRY-LEVEL COVARIATES INCLUDED IN MULTILEVEL REGRESSION MODELS

\begin{tabular}{|c|c|c|c|c|c|c|}
\hline Country & GNI & $\begin{array}{c}\text { Social } \\
\text { mobility }\end{array}$ & GINI & $\begin{array}{l}\text { Cultural } \\
\text { arts }\end{array}$ & $\begin{array}{c}\text { Urbanization } \\
\text { (\%) }\end{array}$ & $\begin{array}{c}\text { Size of the service } \\
\text { class (\%) }\end{array}$ \\
\hline Austria & 42.2 & 34.9 & 30.5 & 2.4 & 65.9 & 31.95 \\
\hline Belgium & 41.4 & 56.8 & 27.6 & 2.1 & 97.7 & 15.42 \\
\hline Bulgaria & 4.5 & 53.9 & 36 & 1.8 & 73 & 23.27 \\
\hline Cyprus & 24.1 & 66.8 & 34.3 & 2.2 & 67.3 & 13.93 \\
\hline Czech Republic & 14.4 & 28 & 26.1 & 2 & 73.1 & 21.92 \\
\hline Denmark & 54.7 & 36.7 & 29.1 & 3 & 87.1 & 35.77 \\
\hline East Germany & 39.5 & 29.3 & 30.1 & 2.8 & 74.7 & 34.39 \\
\hline Estonia & 13.2 & 55.4 & 33.2 & 3.2 & 67.8 & 37.68 \\
\hline Finland & 44.2 & 62.4 & 27.1 & 3.3 & 83.8 & 32.86 \\
\hline France & 39 & 64.1 & 33.1 & 2 & 78.8 & 28.05 \\
\hline Great Britain & 44.1 & 50.1 & 32.6 & 3.1 & 81.8 & 41.45 \\
\hline Greece & 25.4 & 59 & 36.7 & 2.1 & 77 & 14.06 \\
\hline Hungary & 11.5 & 44.7 & 30.6 & 2.1 & 69.8 & 11.98 \\
\hline Ireland & 48.6 & 67.8 & 32.5 & 2.5 & 62.4 & 35.81 \\
\hline Italy & 33.6 & 69.2 & 35.2 & 2.1 & 68.6 & 14.78 \\
\hline Latvia & 10.1 & 55.9 & 35.5 & 2.7 & 67.5 & 32.41 \\
\hline Lithuania & 10 & 61.1 & 35.2 & 2.5 & 66.6 & 33.19 \\
\hline Luxembourg & 74.5 & 47.3 & 34.8 & 1.8 & 89.2 & 32.59 \\
\hline Malta & 16.7 & 56.1 & 27.4 & 2.3 & 95 & 32.93 \\
\hline Netherlands & 46.3 & 55.7 & 28 & 3.8 & 88.6 & 40.17 \\
\hline Northern Ireland & 44.1 & 54.5 & 32.6 & 3.1 & 81.8 & 29.20 \\
\hline Poland & 9.8 & 48.5 & 32.4 & 1.7 & 60.7 & 19.26 \\
\hline Portugal & 19.9 & 56.3 & 36 & 1.4 & 61.8 & 23.71 \\
\hline Romania & 6.4 & 57.8 & 34.9 & 1.1 & 54.1 & 20.65 \\
\hline Slovakia & 14.3 & 44.8 & 26.1 & 1.8 & 54.2 & 19.02 \\
\hline Slovenia & 21.5 & 54.3 & 25.6 & 2.3 & 49.9 & 31.17 \\
\hline Spain & 29.4 & 64.2 & 35.9 & 2.1 & 78.9 & 22.35 \\
\hline Sweden & 48.9 & 67.4 & 27.3 & 3.5 & 85.4 & 44.00 \\
\hline West Germany & 39.5 & 29.3 & 30.1 & 2.8 & 74.7 & 40.46 \\
\hline
\end{tabular}

Notes: GNI = Gross National Income. Social mobility = the percentage of people in a country who attained a higher final educational level than their father and/or mother (Hek and Kraaykamp 2013). GINI is taken from the World Bank. Cultural arts = the level of government spending per capita on funding the cultural arts, Size of the service class $(\%)=$ the proportion of the employed population in service occupations. 


\section{WeB APPENDIX 4: COMPARING EMPLOYMENT AND CLASS IDENTITY PRE- DICTORS OF HIGHBROW CONSUMPTION ACROSS 30 REGIONS}

\begin{tabular}{l}
$\begin{array}{l}\text { Measures of occupation } \\
\text { and class identity }\end{array}$ \\
\hline $\begin{array}{l}\text { Routine manual (baseline) } \\
\text { Routine non-manual }\end{array}$ \\
$\begin{array}{l}\text { Self-employed } \\
\text { Lower Professional }\end{array}$ \\
$\begin{array}{l}\text { Professional } \\
\text { Identify as working-class (baseline) }\end{array}$ \\
$\begin{array}{l}\text { Identify as middle-class } \\
\text { participation [95\% CI] }\end{array}$
\end{tabular}

Notes: Vertical bars are $95 \%$ confidence intervals 
WeB APPENDIX 5: DESCRIPTIVE DATA ON CLASS COMPOSITION AND HIGHBROW CONSUMPTION ACROSS COUNTRIES

\begin{tabular}{|c|c|c|c|c|c|}
\hline Country & $\begin{array}{c}\% \\
\text { identifying } \\
\text { working- } \\
\text { class }\end{array}$ & $\begin{array}{c}\% \\
\text { identifying } \\
\text { middle or } \\
\text { upper class }\end{array}$ & $\begin{array}{l}\text { \% giving } \\
\text { another } \\
\text { response } \dagger\end{array}$ & $\begin{array}{c}\text { Average level } \\
\text { of highbrow } \\
\text { consumption } \\
\text { (scale } 0-3)\end{array}$ & Sample size \\
\hline Austria & 30.04 & 62.14 & 7.82 & 0.77 & 1021 \\
\hline Belgium & 33.1 & 65.3 & 1.6 & 0.92 & 1000 \\
\hline Bulgaria & 59.72 & 31.83 & 8.45 & 0.69 & 1018 \\
\hline Croatia & 50.6 & 46.5 & 2.9 & 0.74 & 1000 \\
\hline Cyprus & 49.7 & 43.76 & 6.53 & 0.52 & 505 \\
\hline Czech Republic & 39.3 & 57.2 & 3.5 & 0.92 & 1000 \\
\hline Denmark & 23.9 & 74.7 & 1.4 & 1.39 & 1004 \\
\hline Estonia & 48.85 & 43.27 & 7.88 & 1.27 & 1003 \\
\hline Finland & 36.69 & 59.82 & 3.5 & 1.17 & 1001 \\
\hline France & 33.98 & 63.98 & 2.04 & 1.13 & 1027 \\
\hline Germany, East & 48.99 & 47.51 & 3.49 & 1.01 & 543 \\
\hline Germany, West & 29.81 & 66.32 & 3.87 & 0.91 & 956 \\
\hline Great Britain & 49.8 & 43.14 & 7.06 & 1.17 & 1006 \\
\hline Greece & 54.8 & 44.3 & 0.9 & 0.42 & 1000 \\
\hline Hungary & 61.08 & 31.07 & 7.84 & 0.58 & 1033 \\
\hline Ireland & 42.32 & 51.89 & 5.8 & 0.95 & 1000 \\
\hline Italy & 35.63 & 59.25 & 5.12 & 0.61 & 1016 \\
\hline Latvia & 52.09 & 44.83 & 3.08 & 1.12 & 1006 \\
\hline Lithuania & 47.61 & 46.65 & 5.75 & 1.07 & 1027 \\
\hline Luxembourg & 18.81 & 80.4 & 0.8 & 1.10 & 505 \\
\hline Malta & 46.8 & 52.4 & 0.8 & 0.91 & 500 \\
\hline Netherlands & 19.33 & 77.73 & 2.94 & 1.39 & 1019 \\
\hline Northern Ireland & 62.67 & 28 & 9.33 & 0.91 & 300 \\
\hline Poland & 51.3 & 45.1 & 3.6 & 0.65 & 1000 \\
\hline Portugal & 78.72 & 14.29 & 6.99 & 0.46 & 1014 \\
\hline Romania & 42.16 & 52.1 & 5.75 & 0.55 & 1025 \\
\hline Slovakia & 44.2 & 53.2 & 2.6 & 0.83 & 1000 \\
\hline Slovenia & 42.28 & 52.41 & 5.3 & 1.04 & 1017 \\
\hline Spain & 68.79 & 30.71 & 0.5 & 0.86 & 1003 \\
\hline Sweden & 20.28 & 77.63 & 2.1 & 1.67 & 1006 \\
\hline
\end{tabular}

Notes: $\dagger$ - other responses include: refused, don't know, other, or none. 
Web ApPENDIX 6: ASSOCIATION BETWEEN NATIONAL-LEVEL CLASS IDENTIFICATION AND HIGHBROW CONSUMPTION, USING ALTERNATIVE DEPENDENT VARIABLES, ACROSS 30 REGIONS

\begin{tabular}{lcc}
\hline & $\begin{array}{c}\text { Number and } \\
\text { frequency of } \\
\text { activities }\end{array}$ & $\begin{array}{c}\text { Culturally } \\
\text { activity }\end{array}$ \\
\hline Individual covariates & $(1)$ & $(2)$ \\
Proportion of people who view themselves as & $-0.031^{*}$ & $\mathrm{X}$ \\
working class & $(0.015)$ & -0.0012 \\
Social class identification $(0=$ Working-class) & & $(0.00098)$ \\
Middle- or Higher class & $1.72^{* *}$ & \\
Not reported & $(0.18)$ & $0.15^{* *}$ \\
& $1.65^{* *}$ & $(0.017)$ \\
\% Working class x individual identifies with & $(0.44)$ & $0.12^{* *}$ \\
middle- or higher-class & $-0.011^{* *}$ & $(0.042)$ \\
\% Working class x individual does not & $(0.0039)$ & $-0.0019^{* *}$ \\
identify with social class & & $(0.00037)$ \\
Constant & $-0.028^{* *}$ & \\
\hline Variance of the random intercepts & $(0.0089)$ & $-0.0019^{*}$ \\
Variance of the individual-level residuals & & $(0.00085)$ \\
\hline Observations & -1.32 & $-0.29^{* *}$ \\
\hline Regions & $(0.76)$ & $(0.052)$ \\
\hline
\end{tabular}

Notes: Model also adjusts for age, gender, age-squared, education, labour market status, marital status, and community size. Standard errors in parentheses and are clustered at the country-level. Dependent variable in model 1 measures the number and frequency of activities respondents have participated in during the last 12 months (0-21). Dependent variable in model 2 compares people with low or medium cultural activity to everyone else. ${ }^{*} \mathrm{p}<0.05,{ }^{* *} \mathrm{p}<0.01$ 


\section{WeB ApPENDIX 7: ASSOCIATION BETWEEN NATIONAL-LEVEL CLASS IDEN- TIFICATION AND HIGHBROW CONSUMPTION AMONG PROFESSIONALS WHO IDENTIFY AS MIDDLE-CLASS AND ROUTINE MANUAL WORKERS WHO IDEN- TIFY AS WORKING-CLASS}

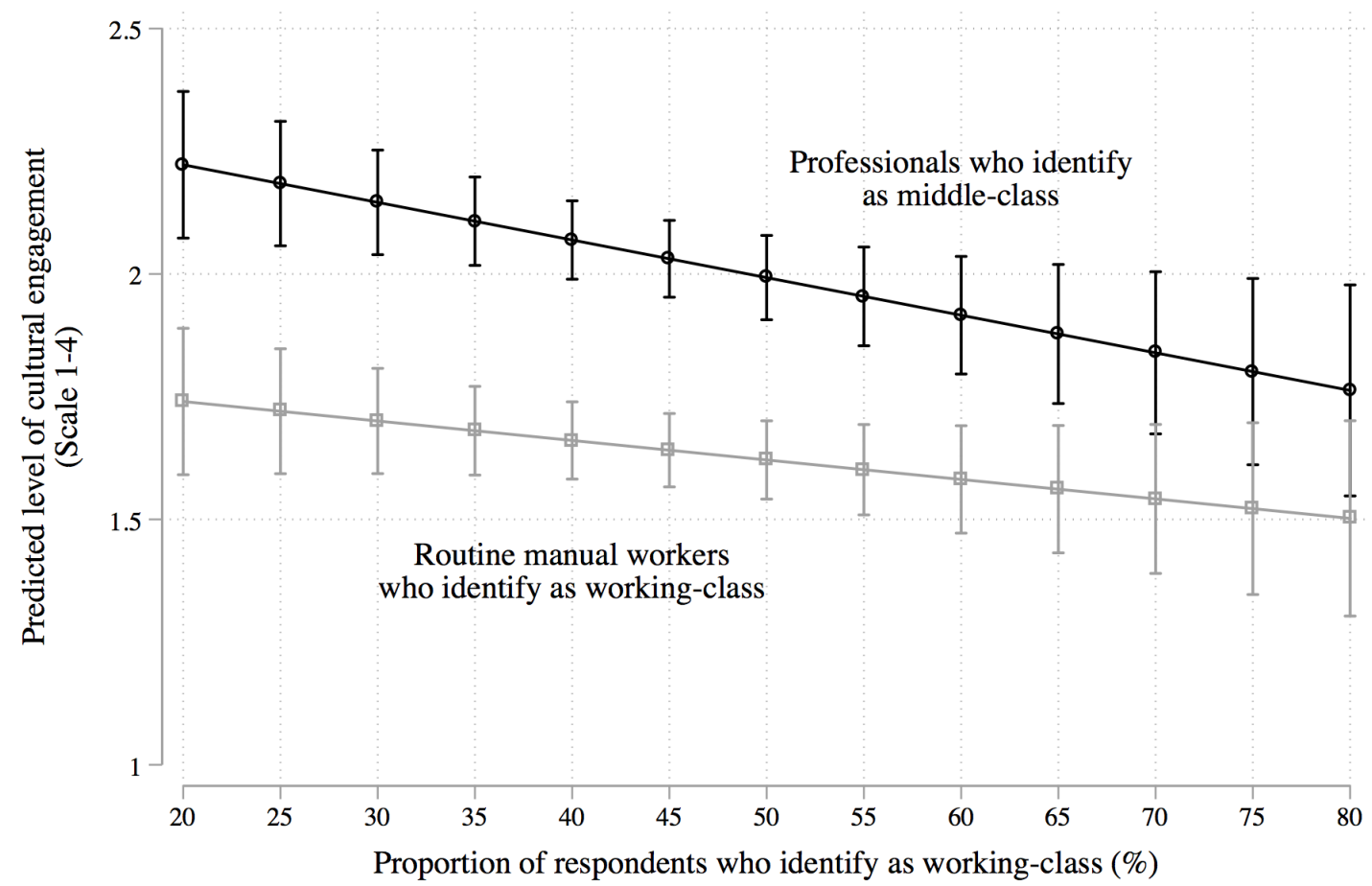

Notes: Model adjusts for interactions between all labour market positions and the proportion of respondents who identify as working-class. 


\section{WeB APPENDIX 8: ASSOCIATION BETWEEN NATIONAL-LEVEL CLASS IDEN- TIFICATION AND HIGHBROW CONSUMPTION, MEASURING THE PROPORTION OF PEOPLE WHO CONSIDER THEMSELVES 'HIGH-LEVEL', ACROSS 30 REGIONS}

\begin{tabular}{lc}
\hline & $\begin{array}{c}\text { Highbrow } \\
\text { consumption }\end{array}$ \\
\hline Individual covariates & $\mathrm{X}$ \\
Proportion of people who view themselves as 'high-level' & $0.87^{* *}$ \\
& $(0.28)$ \\
Position in society (scores 1-6) & \\
High psoition (scores 7-10) & $0.097^{* *}$ \\
\% 'high-level' x individual identifies as 'high-level' & $(0.012)$ \\
& $0.23^{* *}$ \\
Constant & $(0.086)$ \\
& \\
\hline Variance of the random intercepts & $-0.49^{* *}$ \\
Variance of the individual-level residuals & $(0.061)$ \\
\hline Observations & 0.035 \\
Regions & $(0.009)$ \\
\hline Notes: Stal & 0.54 \\
\hline
\end{tabular}

Notes: Standard errors in parentheses and are clustered at the country-level. Individuals are asked to describe their level in society? Respondents can select one of three options (low, middle, or high). ${ }^{*} \mathrm{p}<0.05,{ }^{* *} \mathrm{p}<0.01$ 
WeB APPENDIX 9: ASSOCIATION BETWEEN NATIONAL-LEVEL CLASS IDENTIFICATION AND HIGHBROW CONSUMPTION, ADJUSTING FOR COUNTRY-LEVEL COVARIATES, ACROSS 30 REGIONS

\begin{tabular}{|c|c|c|c|c|c|c|c|c|}
\hline & \multicolumn{8}{|c|}{ Highbrow consumption } \\
\hline & $(1)$ & (2) & (3) & (4) & (5) & $(6)$ & $(7)$ & $(8)$ \\
\hline Proportion of people who view & -0.0044 & -0.0014 & -0.0045 & -0.00026 & -0.0024 & -0.0023 & 0.00090 & 0.0033 \\
\hline themselves as working class & $(0.0027)$ & $(0.0032)$ & $(0.0027)$ & $(0.0021)$ & $(0.0030)$ & $(0.0027)$ & $(0.0019)$ & $(0.0019)$ \\
\hline \multicolumn{9}{|l|}{ Social class interactions } \\
\hline \% Working class $\mathrm{x}$ individual identifies & $-0.0029^{* * *}$ & $-0.0030^{* * *}$ & $-0.0031^{* * *}$ & $-0.0031^{* * * *}$ & $-0.0030^{* * *}$ & $-0.0029^{* * *}$ & $-0.0029^{* * *}$ & $-0.0031^{* * *}$ \\
\hline with middle- or higher-class & $(0.00076)$ & $(0.00076)$ & $(0.00076)$ & $(0.00076)$ & $(0.00076)$ & $(0.00076)$ & $(0.00075)$ & $(0.00076)$ \\
\hline \% Working class $\mathrm{x}$ individual does & $-0.0051^{* *}$ & $-0.0052^{* *}$ & $-0.0052^{* *}$ & $-0.0052^{* *}$ & $-0.0052^{* *}$ & $-0.0052^{* *}$ & $-0.0051^{* *}$ & $-0.0052^{* *}$ \\
\hline not identify with social class & $(0.0017)$ & $(0.0017)$ & $(0.0017)$ & $(0.0017)$ & $(0.0017)$ & $(0.0017)$ & $(0.0017)$ & $(0.0017)$ \\
\hline \multirow[t]{2}{*}{ GNI } & & 0.0040 & & & & & & -0.00071 \\
\hline & & $(0.0027)$ & & & & & & $(0.0016)$ \\
\hline \multirow[t]{2}{*}{ Social Mobility } & & & 0.0019 & & & & & $0.0043^{*}$ \\
\hline & & & $(0.0034)$ & & & & & $(0.0018)$ \\
\hline Public spending on & & & & $0.25^{* * *}$ & & & & 0.030 \\
\hline cultural activities & & & & $(0.048)$ & & & & $(0.050)$ \\
\hline \multirow[t]{2}{*}{ GINI } & & & & & -0.017 & & & $-0.017^{*}$ \\
\hline & & & & & $(0.012)$ & & & $(0.0070)$ \\
\hline Proportion of the population & & & & & & $0.0068^{*}$ & & $0.0044^{*}$ \\
\hline living in urban areas & & & & & & $(0.0031)$ & & $(0.0020)$ \\
\hline Proportion of the labour market & & & & & & & $1.96^{* * *}$ & $1.78^{* * *}$ \\
\hline employed in the service class & & & & & & & $(0.29)$ & $(0.32)$ \\
\hline Obervations & 26480 & 25539 & 25539 & 25539 & 26480 & 26480 & 26480 & 25539 \\
\hline Regions & 30 & 30 & 30 & 30 & 30 & 30 & 30 & 30 \\
\hline
\end{tabular}

Notes: Standard errors in parentheses and are clustered at the country-level. Coefficients for the interaction terms appear stable across models due to rounding. All individual-level covariates are included in the model but not reported. Constant estimated but not reported. Variance of the random intercepts and the individual-level residuals are estimated but not reported. ${ }^{*} \mathrm{p}<0.05,{ }^{* *} \mathrm{p}<0.01$ 
WeB APPENDIX 10: ASSOCIATION BETWEEN NATIONAL-LEVEL CLASS IDENTIFICATION AND HIGHBROW CONSUMPTION, COMBINING VERY SIMILAR REGIONS, ACROSS 28 REGIONS

\begin{tabular}{|c|c|c|}
\hline & \multicolumn{2}{|c|}{ Highbrow consumption } \\
\hline & 30 regions & 28 regions \\
\hline & (1) & (2) \\
\hline Individual covariates & $\mathrm{X}$ & $\mathrm{X}$ \\
\hline Proportion of people who view themselves as & -0.0044 & 0.00079 \\
\hline working class & $(0.0027)$ & $(0.0016)$ \\
\hline \multicolumn{3}{|l|}{ Social class identification $(0=$ Working-class $)$} \\
\hline \multirow[t]{2}{*}{ Middle- or Higher class } & $0.30^{* *}$ & $0.29^{* *}$ \\
\hline & $(0.035)$ & $(0.035)$ \\
\hline \multirow[t]{2}{*}{ Not reported } & $0.30^{* *}$ & $0.30^{* *}$ \\
\hline & $(0.085)$ & $(0.085)$ \\
\hline \multirow{2}{*}{$\begin{array}{l}\text { \% Working class } \mathrm{x} \text { individual identifies with } \\
\text { middle- or higher-class }\end{array}$} & $-0.0029^{* *}$ & $-0.0027^{* *}$ \\
\hline & $(0.00076)$ & $(0.00075)$ \\
\hline \multirow{2}{*}{$\begin{array}{l}\text { \% Working class } \mathrm{x} \text { individual does not identify } \\
\text { with social class }\end{array}$} & $-0.0051^{* *}$ & $-0.0052^{* *}$ \\
\hline & $(0.0017)$ & $(0.0017)$ \\
\hline \multirow[t]{2}{*}{ Constant } & $-0.34^{*}$ & $-0.58^{* *}$ \\
\hline & $(0.13)$ & $(0.096)$ \\
\hline \multirow[t]{2}{*}{ Variance of the random intercepts } & 0.042 & 0.050 \\
\hline & $(0.011)$ & $(0.014)$ \\
\hline \multirow[t]{2}{*}{ Variance of the individual-level residuals } & 0.54 & 0.54 \\
\hline & $(0.0047)$ & $(0.0047)$ \\
\hline Observations & 26487 & 26487 \\
\hline Regions & 30 & 28 \\
\hline
\end{tabular}

Notes: Standard errors in parentheses and are clustered at the country-level. Northern Ireland is merged with Great Britain to form the UK and East and West Germany are combined. ${ }^{*} \mathrm{p}<0.05,{ }^{* *} \mathrm{p}<0.01$ 


\section{WeB ApPENDIX 11: ASSOCIATION BETWEEN NATIONAL-LEVEL CLASS IDEN- TIFICATION AND HIGHBROW CONSUMPTION, INCLUDING ONLY THOSE AGED 25-75 AND THOSE WHO ARE NOT IN FULL-TIME EDUCATION, ACROSS 30 RE- GIONS}

\begin{tabular}{lc}
\hline & Highbrow consumption \\
& $(1)$ \\
\hline Individual covariates & $\mathrm{X}$ \\
Proportion of people who view themselves as working class & -0.0038 \\
& $(0.0027)$ \\
Social class identification $(0=$ Working-class) & \\
Middle- or Higher class & $0.16^{* *}$ \\
& $(0.012)$ \\
Not reported & $0.092^{* *}$ \\
\% Working class x individual identifies with middle- or higher-class & $(0.028)$ \\
& $-0.0037^{* *}$ \\
\% Working class x individual does not identify with social class & $(0.00084)$ \\
& \\
Variance of the individual-level residuals & $-0.0068^{* *}$ \\
\hline Observations & $(0.0021)$ \\
\hline Variance of the random intercepts & $-0.37^{* *}$ \\
& $(0.089)$ \\
\hline & 0.042 \\
& $(0.011)$ \\
& 0.53 \\
& $(0.0052)$ \\
\hline & 21155 \\
& 30 \\
\hline
\end{tabular}

Notes: Standard errors in parentheses and are clustered at the country-level. ${ }^{*} \mathrm{p}<0.05,{ }^{* *} \mathrm{p}<0.01$ 
WeB APPENDIX 12: BOOTSTRAPPED CROSS-LEVEL INTERACTION TERM BETWEEN IDENTIFYING MIDDLE-CLASS AND THE LEVEL OF MIDDLE-CLASS IDENTIFICATION, SEQUENTIALLY REMOVING ONE COUNTRY FROM EACH MODEL, ACROSS 30 REGIONS.

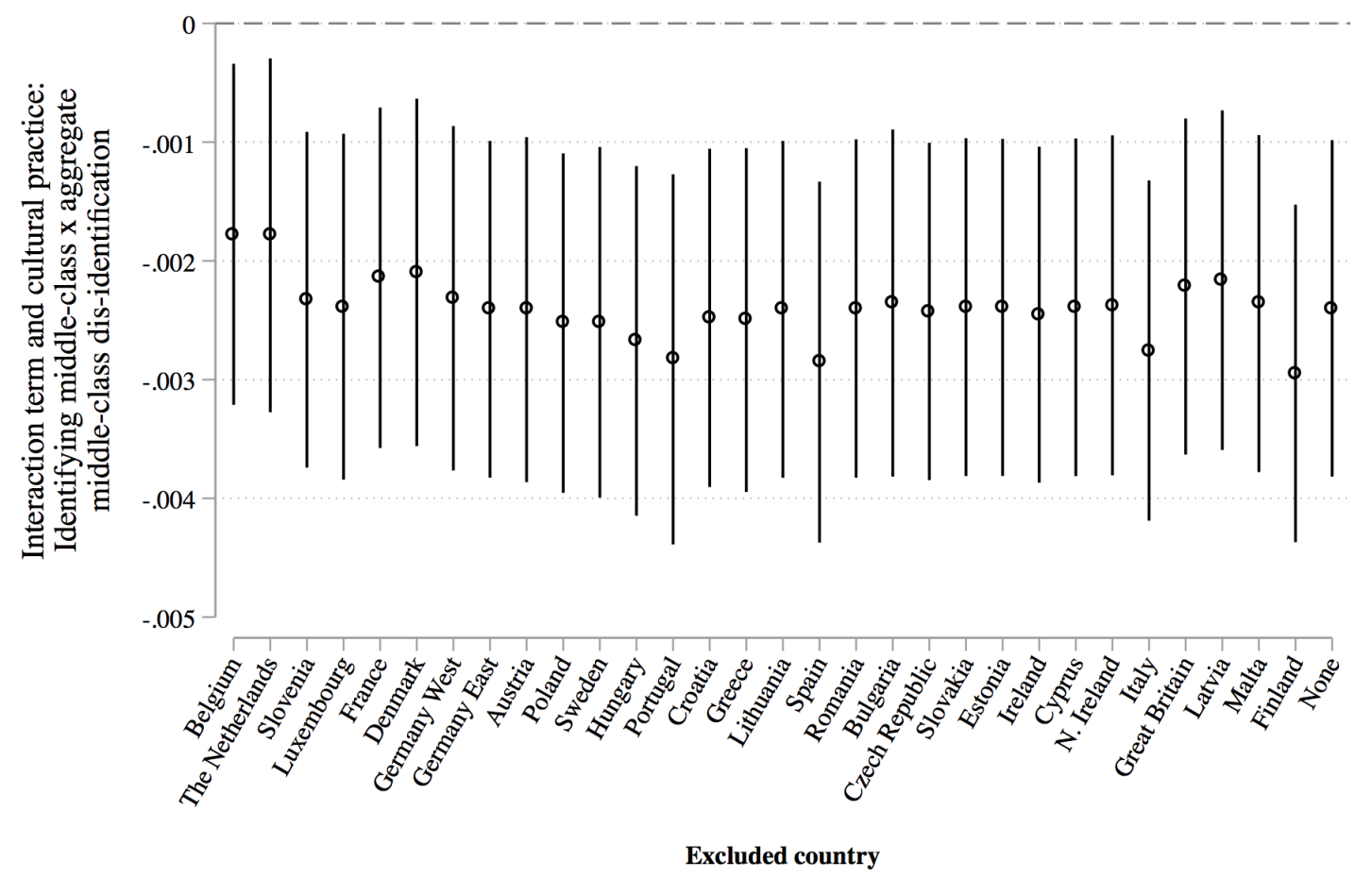

Notes: Each coefficient comes from a different model. In each model one country is removed (the named country at the bottom of the graph) and then the model is re-estimated. The exception is the final model where all countries are included. This replicates the main model reported in the paper. 


\section{WeB ApPendix 13: AsSOCIATION BETWEEN NATIONAL-LEVEL CLASS IDEN- TIFICATION AND HIGHBROW CONSUMPTION, ACROSS 30 REGIONS, WITH WEIGHTS}

\begin{tabular}{lcc}
\hline & \multicolumn{2}{c}{ Highbrow consumption } \\
& $(1)$ & $(2)$ \\
\hline Individual covariates & $\mathrm{X}$ & $\mathrm{X}$ \\
Proportion of people who view themselves as & $-0.0067^{* *}$ & $-0.0056^{*}$ \\
working class & $(0.0025)$ & $(0.0024)$ \\
& & \\
Social class identification $(0=$ Working-class) & & $0.16^{* *}$ \\
Middle- or Higher class & & $(0.023)$ \\
& & 0.042 \\
Not reported & & $(0.031)$ \\
& $-0.48^{* *}$ & $-0.52^{* *}$ \\
Constant & $(0.10)$ & $(0.10)$ \\
& 0.040 & 0.041 \\
Variance of the random intercepts & $(0.008)$ & $(0.008)$ \\
Variance of the individual-level residuals & 0.55 & 0.54 \\
& $(0.020)$ & $(0.020)$ \\
\hline Observations & 26487 & 26487 \\
Regions & 30 & 30 \\
\hline
\end{tabular}

Notes: Model also adjusts for age, gender, age-squared, education, labour market status, marital status, and community size. Standard errors in parentheses and are clustered at the country-level. Both models are weighted using post-stratification weights. ${ }^{*} \mathrm{p}<0.05,{ }^{* *} \mathrm{p}<0.01$ 
WeB Appendix 14: CLASS IDENTIFICATION MODERATES THE ASSOCIATION BETWEEN CLASS IDENTIFICATION AND HIGHBROW CONSUMPTION, USING WEIGHTS

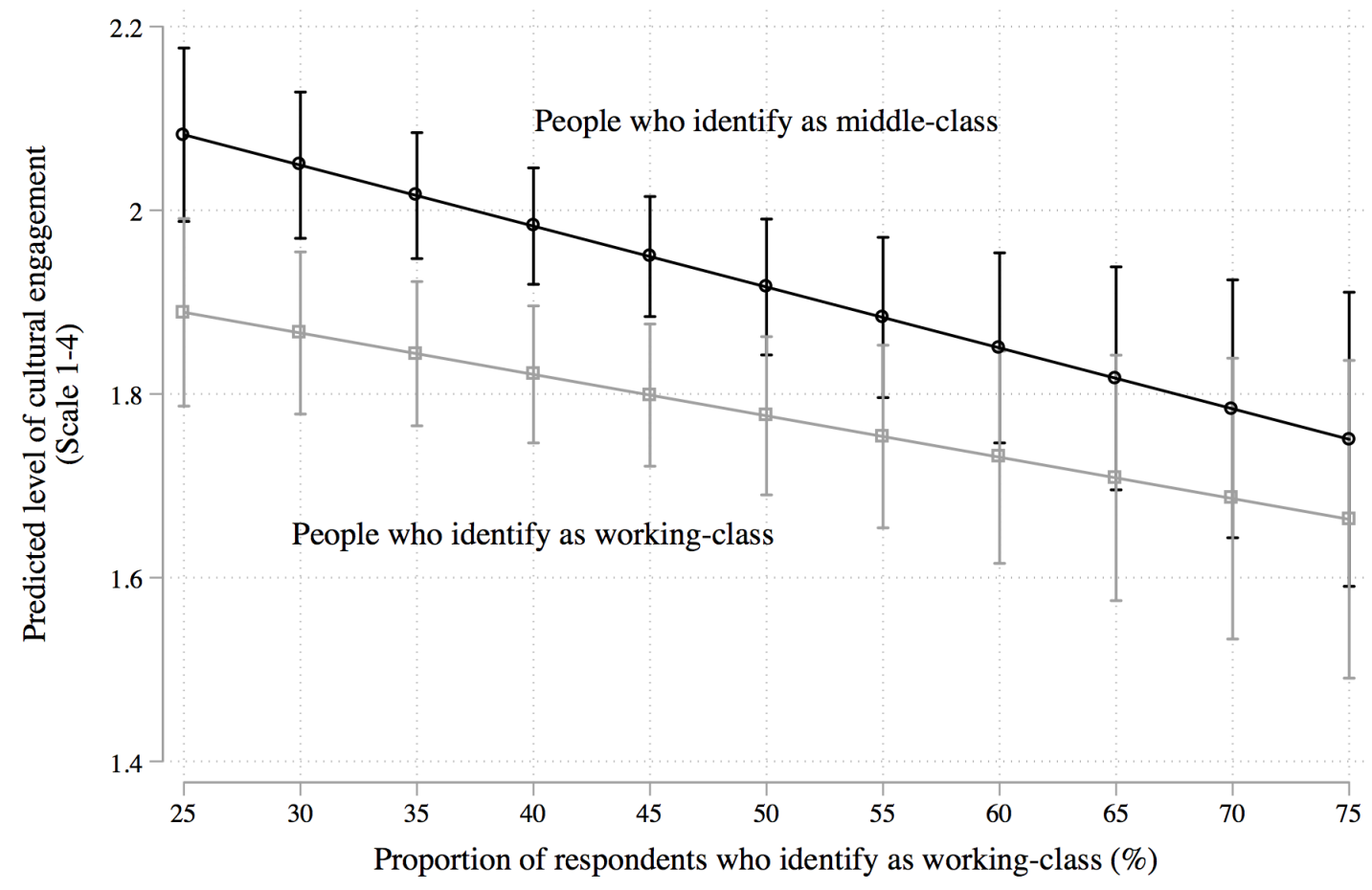

Notes: Vertical bars are $95 \%$ confidence intervals 